NBER WORKING PAPER SERIES

\title{
WHY ARE THE CRITICS SO CONVINCED THAT GLOBALIZATION IS BAD FOR THE POOR?
}

\author{
Emma Aisbett \\ Working Paper 11066 \\ http://www.nber.org/papers/w11066 \\ NATIONAL BUREAU OF ECONOMIC RESEARCH \\ 1050 Massachusetts Avenue \\ Cambridge, MA 02138 \\ January 2005
}

The views expressed herein are those of the author(s) and do not necessarily reflect the views of the National Bureau of Economic Research.

(C) 2005 by Emma Aisbett. All rights reserved. Short sections of text, not to exceed two paragraphs, may be quoted without explicit permission provided that full credit, including (C) notice, is given to the source. 
Why are the Critics so Convinced that Globalization is Bad for the Poor?

Emma Aisbett

NBER Working Paper No. 11066

January 2005

JEL No. F0

\begin{abstract}
Proponents of globalization often conclude that its critics are ignorant or self-motivated. In doing so, they have missed a valuable opportunity to discover both how best to communicate the benefits of globalization, and how to improve on the current model of globalization. This paper examines the values, beliefs and facts that lead critics to the view that globalization is bad for the poor. We find that critics of globalization tend to be concerned about non-monetary as well as monetary dimensions of poverty, and more concerned about the total number of poor than the incidence of poverty. In regard to inequality, critics tend to refer more to changes in absolute inequality, and income polarization, rather than the inequality measures preferred by economists. It is particularly important to them that no group of poor people is made worse off by globalization. Finally, we argue that the perceived concentration of political and economic power that accompanies globalization causes many people to presume that globalization is bad for the poor, and the continued ambiguities in the empirical findings mean that this presumption can be readily supported with evidence.

Emma Aisbett

Department of Agricultural and Resource Economics

306 Giannini Hall \#3310

University of California

Berkeley, CA 94720-3310

aisbett@berkeley.edu
\end{abstract}




\section{Introduction}

Economic globalization is a surprisingly controversial process. Surprising, that is, to the many economists and policy makers who believe it is the best means of bringing prosperity to the largest number of people all around the world. Proponents of economic globalization have had a tendency to conclude that dissent and criticism is the result of ignorance or vested interest (Bardhan, 2003). They have argued that anti-sweatshop campaigners do not understand that conditions in the factories owned by multi-nationals tend to be better than those in comparable domestic firms; that environmentalists are denying the world's poor of the right to develop freely; and unionists in developed countries are protecting their interests at the expense of the workers in poorer parts of the world.

Bhagwati (2000, p.134) provides a good example of the way that some proponents of globalization have reacted to critics:

"No one can escape the antiglobalists today.....This motley crew comes almost entirely from the rich countries and is overwhelmingly white, largely middle class, occasionally misinformed, often wittingly dishonest, and so diverse in its professed concerns that it makes the output from a monkey's romp on a keyboard look more coherent."

More recently, however, leading economists and policy-makers, including Bhagwati (2004, p.4), have been advocating for 'reasoned engagement' and 'careful response' to some of the more mainstream critics of globalization. There is a growing sense of the value of doing more than knocking down the straw men put forward by the extreme or the misinformed. As Stanely Fischer (2003, p.2) says:

"The debate [over globalization] is untidy and ill-defined, and one could react by saying that it has no place in a professional setting like this one. But we cannot afford to ignore it, for the views and attitudes expressed in it will inevitably affect public policy - and the issues are critically important for the future economic growth and well-being of people all the people of the globe." 
The aim of this paper is to help explain both the 'what' and the 'why' of common criticisms of globalization's record on poverty and inequality. In particular, it addresses the question of why many people in rich countries believe that globalization has been bad for the poor in developing countries, and has worsened inequality. ${ }^{1}$

The answer to our question consists essentially of two parts. First, that neither the theory nor the empirical evidence on globalization and poverty is unarguably positive. Second, and more importantly, that people's interpretation of the available evidence is strongly influenced by their values and by their beliefs about the process of globalization.

Evidence for the first part of our argument is presented in Sections $2 \&$ 3. Section 2 discusses the large amount of empirical work that has tried to identify causal links between globalization, poverty and inequality. We argue here that the linkages between globalization policies and poverty outcomes remain theoretically unclear and difficult to test empirically, and that more nuanced empirical research is required to address the remaining concerns with regard to globalization. Section 3 discusses some key trends in poverty and inequality numbers over the current 'period of globalization'. Here we argue that the wide range of poverty and inequality estimates, which arises from apparently minor methodological differences, leaves ample room for a difference in opinion about the achievements of the last 25 years.

Sections $4 \& 5$ comprise the second part of our answer. Section 4 shows that critics of globalization often have different conceptions of poverty and inequality than those preferred by economists. Section 5 argues that people are predisposed to thinking globalization is bad for the poor because they view the power structures of globalization as being biased towards the already rich and powerful. Section 6 summarizes and concludes.

Before attempting to explain 'anti-globalization' sentiment, it is worthwhile clarifying what is meant by globalization and anti-globalization in the context of this paper. That is the subject of the remainder of this section.

\footnotetext{
${ }^{1}$ A recent survey conducted by the World Economic Forum (WEF, 2002) found that people in richer countries were
} more likely than people in poorer countries to believe that globalization benefited the poor less than the rich. 


\subsection{Globalization}

Despite the fact that the definition of globalization has been attempted by hundreds of authors and distinguished speakers on the topic, the word continues to mean very different things to different people. In light of this, we do not attempt any general definition of globalization, but rather explain what is meant by globalization in the context of this paper.

In this paper, globalization refers to global economic integration, or 'economic globalization'. Economic globalization, including increases in trade, foreign investment, and migration, is widely agreed to be occurring through a combination of improvements in technology and decreased transportation costs, as well as deliberate policy choices on behalf of many national governments to liberalize their economies and participate in the development of global institutions. Thus the policy aspect of economic globalization is a cumulative outcome that results from the choices of many individual countries to increase their integration with the global economy. ${ }^{2}$

Given that globalization may be viewed as the cumulative result of increased integration on behalf of many individual countries, we need to consider how individual countries become integrated into the global economy. There are two broad approaches to measuring the extent to which a country is integrated with the global economy. The first approach is to determine the level of restrictions placed on the movement of goods, services and factors into and out of the country. Thus an absence of trade restrictions, liberalized capital markets, and free movement of labor could all be considered indicators of an integrated economy. The second measure of a country's

${ }^{2}$ This idea that globalization is the aggregate result of individual country liberalization is made by Prasad et al. (2003). Though it will not be a major issue in this paper, it is worth noting that the impact on a country of its own integration may be different from the impact of exogenous increases in globalization. Consider the case of Mexico. The impact of its own efforts at liberalization and integration may be to increase foreign trade and investment. At the same time, however, many other low and middle-income countries have been integrating, which leads to more competition for foreign capital and export markets. Thus exogenous increases in the level of global economic integration (i.e. economic globalization), and increases in Mexico's own level of integration, may have exactly opposite effects on the level of trade and investment in that country. Indeed this example is not far from reality. One of the conclusions of the Trade and Development Report, 2002 (UNCTAD, p.IX) is that middle income countries such as those in Latin America and South-East Asia will need to rapidly upgrade their skill intensive manufactures if they are to stay ahead of competition from low-income countries that are becoming increasingly export-oriented. 
integration is the relative size of the flows of goods, services, factors, and profits into and out of the country. While these two measures are often used interchangeably, they are not identical concepts, and are not even highly correlated empirically (Harrison, 1996). Consider export subsidies. Viewed from the first perspective, these programs are akin to tariffs, and are decidedly contrary to the principle of economic globalization. Yet viewed from the second perspective, these programs can be seen to greatly increase the level of integration achieved. Indeed, having read many arguments from both sides, it seems to me that this ambiguity is a major reason that some people claim that the East Asian Tiger's success was based on pro-integration policies, while others claim the exact opposite.

The distinction between policies and outcomes is important to the globalization debate. Analysis of popular writings and opinion surveys suggest that most people are happy with increases in trade in principle, yet they view policies of unregulated free markets and minimal government involvement much less favorably. ${ }^{3}$

Another linguistic issue of relevance to understanding the globalization debate is that criticisms of globalization are often actually criticisms of a broader neo-liberal policy agenda that globalization is believed to imply. Burgess (forthcoming, p.1) makes this point when he describes the difference between what economists (typically proponents of globalization) and public health advocates (often critics) mean when they refer to globalization/liberalization:

"Whereas trade economists interpret liberalization to mean policies that eliminate trade and capital barriers at international borders, public health advocates consider the domestic policy changes that third world governments are obliged to accept in order to become full-fledged members of the IMFWorld Bank-Davos club of nations.”

\footnotetext{
${ }^{3}$ For example, based on surveys of 18,797 people in 19 countries, Globscan reports that majorities in all countries except the United States (US) support opening up markets to poor countries. In the US support for opening up to poor countries was premised on the supply of increased government support for those who loose their jobs as a result of increased imports. Similarly, in a report that brings together all the available evidence on public opinion in the US, the Program on International Policy Attitudes (PIPA, 2002) finds that most Americans do agree with free trade in principle, however, their support is contingent on complementary policies to address social and environmental concerns, as well as American job losses.
} 


\section{2. 'Anti-Globalization'}

Despite its popularity and convenience, in the remainder of this paper we avoid referring to the 'anti-globalization movement'. There are two reasons for this. Firstly, many of the concerns and positions that I discuss may be attributed to a far broader segment of the population than that which is actively involved in any movement. The use of such a label, and its application to street protesters, has a divisive effect between groups who in reality share many of the same concerns. In particular, it forces a wedge between academic economists and the concerned public.

Secondly, as has been noted by many leading authors ${ }^{4}$, the so-called 'anti-globalization' movement is not uniformly opposed to globalization as it is broadly defined. It is a fact that the movement itself is global, and all the leading writers of the movement reject the 'antiglobalization' label. ${ }^{5}$ Naomi Klein, 'unofficial spokesperson of the movement' has this to say about the term:

"The irony of the media-imposed label, 'anti-globalization,' is that we in this movement have been turning globalization into a lived reality, perhaps more so than even the most multinational of corporate executives. ${ }^{6}$

But what about globalization as defined here? People may enjoy the world-wide-web, and easy international travel, but what about the economic aspects of globalization? As will be argued in the following paragraphs, for the most part people are not opposed to the principle of global economic integration. They are, however, critical of the way in which it is currently progressing, and they do believe that the optimal level of integration will allow space for national sovereignty, democracy, and some government intervention to advance social and environmental agendas. We refer to these individuals as 'critics of globalization', and reserve the label 'anti-globalization' for people who would genuinely like to stop globalization dead in its tracks. Globalization's 'critics' will be the focus of this paper.

\footnotetext{
${ }^{4}$ See for example Sen (2002); Kanbur (2001); Ravallion (2003), Bhagwati (2004)

${ }^{5}$ See for example Kortan (1996)

${ }^{6}$ Quoted in Chihara (2002)
} 


\section{Questionable Causation}

As noted by Bardhan (2003), both sides of the globalization debate have had a tendency to claim an unreasonable degree of causation between liberalizing policies and observed trends in poverty and inequality. The claims of causation are so confounded that both sides claim the success of the Asian tigers as the result of their own policies, and the failure of many of the African states as the result of the opposite policies. Thus globalization's proponents claim China and Taiwan's growth in recent decades as the result of liberalization of their economies, while globalization's critics claim that these same countries have been able to capitalize on the opportunities afforded by globalization because of extensive government intervention both in the past and present.

Similarly, globalization's proponents claim that many of Africa's economic problems are due to lack of openness and excessive, inappropriate government intervention. Globalization's critics claim that Africa's woes come from other sources (including corrupt or incompetent governments), but the forced liberalization imposed by structural adjustment programs and other lending conditions has not delivered the promised growth. Instead globalization has only made living conditions worse for the poor as government services are cut back, and instability increased.

An enormous research effort has been expended by economists in an attempt resolve these contradictory claims. This section will summarize the types of empirical research that have been conducted, and identify a set of stylized facts that have emerged from it. It then discusses why the empirical literature has not been as successful as many practitioners would hope in convincing skeptics of the benefits of globalization.

Before proceeding, it is important to make clear what the current section and the following section on measurement of poverty and inequality do and, more importantly, do not try to achieve. Neither of them is in any way a comprehensive assessment of the literature which they are discussing. They do not aim to produce a statement of the type "overall the empirical evidence 
supports the conclusion that globalization is good/bad for the poor."7 Quite the contrary, their aim is to show how the empirical evidence to date leaves ample room for debate about the impact of globalization on the poor. Accordingly, the approach taken in the following sections is to highlight only a few key statistics and empirical methods, as well as their limitations and biases.

Reimer (2002) provides an excellent overview of the different empirical methods that have been employed in research on globalization and their findings. He categorizes the research methods under the following headings:

- Cross-country regression analyses which test for correlations among trade, growth, income, poverty and inequality measured at the national level;

- Partial equilibrium/ cost of living analyses which are typically based on household expenditure data and emphasize commodity markets and their role in determining poverty impacts;

- General equilibrium studies that are generally based on disaggregated economy-wide Social Accounting Matrices, and account for commodity, terms of trade and factor market effects; and the newest approach

- Micro-macro syntheses that involve general equilibrium analysis coupled with some form of post simulation analysis based on household survey data.

One important method for analyzing the impacts of globalization is left off Reimer's list. I describe this category as micro-economic studies that test specific mechanisms (other than prices) through which globalization is believed to impact the poor. The findings of this literature have been summarized in a recent paper by two of the leading authors in this field, Goldberg and Pavcnik (2004).

\footnotetext{
${ }^{7}$ Readers who are interested in more comprehensive assessments of the empirical literature may consider one of the several high quality survey papers, reports, and opinion pieces have already been devoted to these questions. See for example IMF (1997, Chapter IV); UNDP (1999); McKay, Winters \& Kedir (2000); Reimer (2002); Bigman (2002); Berg \& Krueger (2003); Bhagwati \& Srinivasan (2002); Bourguignon et al (2002); Prasad et al. (2003); Baldwin (2003); Pavcnik and Goldberg (2004) \& Winters (2004)
} 
While each empirical approach suffers from its own set of limitations, in combination, the above types of empirical research have been successful in providing several points on which a relatively broad consensus has been reached: ${ }^{8}$

1. Trade is correlated with, and often a source, of growth.

2. Growth is on average good for the poor.

3. U.S. and E.U. should liberalize their trade, particularly in agriculture and textiles.

4. FDI is correlated with, and often a source of, growth.

5. Liberalization of markets for short term capital can be detrimental and should be approached with caution.

6. Governments should provide safety nets to compensate the poor who lose as a result of liberalization.

7. TRIPs should be modified do limit negative impacts on provision of drugs to the poor.

8. Access to education, health, and credit are important factors in ensuring the poor benefit from globalization. These factors also increase the growth potential from openness.

9. Poverty should be measured using education and health as well as income.

10. Excessive corporate power (market and political) is a problem.

11. Capture of market or political power by elites has negative implications for growth and welfare.

12. Political reform is needed in many developing countries.

It is particularly reassuring to observe that these points of consensus in the academic literature have supported the furtive emergence of a middle ground in the public debate over globalization.

${ }^{8}$ See for example: This volume, Harrison, A. (ed) (forthcoming) Globalization and Poverty, NBER; IMF (1997, Chapter IV); UNDP (1999); McKay, Winters \& Kedir (2000); Reimer (2002); Bigman (2002); Berg \& Krueger (2003); Bhagwati \& Srinivasan (2002); Bourguignon et al (2002); Prasad et al. (2004); Baldwin (2003); Pavcnik and Goldberg (2004); Bolaky \& Freund (2004); \& Winters (2004). 
In reading publications from both sides, we observe an increasing number of participants who are wishing to move beyond competing and contradictory monologues and are willing to acknowledge some aspects of the argument presented by 'the other side'. For example, Oxfam International is one of the leading non-governmental organizations campaigning on free trade issues. Their briefing prepared for the Doha round of trade talks begins:

"International trade can be a force for poverty reduction by reducing scarcity, and by creating livelihoods and employment opportunities, but this is not an automatic process. Liberalization is not a panacea for poverty any more than protectionism."

From the other side, we have the Economist magazine, a publication established specifically to promote the free market. Their $75^{\text {th }}$ Birthday special issue on capitalism and democracy identified personal greed on behalf of company executives, a vacuum of ownership in publicly traded firms, and an unsavory degree of mutual vested interest between government and businesses as the major threats to capitalism and democracy (Emmott, 2003).

Heartening as such progress is, there are a large number of unresolved issues that make it impossible to feel that the globalization debate is close to consensus. A summary of remaining disagreements over globalization, poverty and inequality in developing countries is tabulated in Appendix 1. In the remainder of the current section, I consider some of the reasons why such disagreements persist, despite the prodigious research effort that has been exerted by economists to resolve them. In essence I see three reasons for the limited success. Firstly, these are very complex and difficult questions to answer. Secondly, the link between the empirical findings and the policy conclusions has until recently been given insufficient attention. And thirdly, much of the empirical research has not understood the underlying concerns of the critics, and has therefore failed to address the more nuanced but no less pivotal parts of the debate, such as the issues presented in Appendix 1.

The literature on the impacts of globalization faces the same obstacles that the broader literature on growth faces. The trouble begins with the fact that there is no unambiguous 
theoretical outcome, and thus everything must be tested empirically. ${ }^{9}$ The trouble continues because the observable outcomes, growth, inequality, and poverty, are functions of a very large number of both past and present variables, and influence these other variables in return. In short, endogeneity plagues empirical research efforts on globalization.

The result is that it is very difficult to prove in the case of an individual country exactly which factor or combination of factors was responsible for its success or lack thereof. For this reason, it is important to consider the experience of a number of countries. In order to do that, comparable individual country case studies must be conducted, or some form of cross-country comparison made. ${ }^{10}$ The latter method usually involves statistical analysis based on a cross-country regression model.

Cross-country regression studies have proved extremely useful for identifying correlations between relevant variables; however, they suffer some important methodological limitations when used for policy analysis. ${ }^{11}$ Primary amongst these limitations are a lack of exogenous measures of openness, an inability to convincingly establish direction and strength of causality, and the economic simplifications required to use a linear regression framework. These limitations have led several leading economists to conclude that cross-country regressions should not be used as a basis for causal conclusions regarding the impacts of globalization. ${ }^{12}$ These well-known limitations are also one of the reasons that critics of economic globalization remain unconvinced by the generally positive findings of such studies.

It is heartening to see that there is a growing acknowledgement of the limitations of a black box approach to globalization and poverty, and increasing recognition among researchers of the importance of identifying the causal mechanisms through which globalization affects the poor. This approach is increasingly being represented by the contributions of this volume, as well as by Alan Winters (2000, 2002, 2004), and the current UNU-WIDER project on the Impact of

\footnotetext{
${ }^{9}$ Winters (2000); Agenor (2002)

10 The former method was developed and applied very successfully in two projects, one by Little et al (1970) at the OECD and one lead by Bhagwati \& Krueger for the NBER (Bhagwati \& Srinivasan, 2002).

${ }^{11}$ Deaton (1995); Ravallion (2003)

${ }^{12}$ Bhagwati (2000); Bhagwati \& Srinivasan (2002); Bardhan (2003); Ravallion (2003)
} 
Globalization on the World's Poor (UNU-WIDER, 2004).

There is, however, a second reason that the empirical evidence to date has failed to convert critics of economic globalization into proponents. The reason is that the literature has not been well targeted towards addressing the remaining reservations that many people have about globalization. The mismatch between the questions currently being asked, and the answers people want, may be observed with reference to the list of 'Outstanding Disagreements' in Appendix 1.

In my opinion, people do not need to be convinced that growth is generally good for the poor, or that increased trade is generally good for growth. As will be shown in later sections of this paper, the evidence from reading criticisms of globalization is that people are more interested in the optimal policy mix to maximize the benefits to the poor, while minimizing the negative impacts on any subgroup of the poor that is made worse off by such policies. They are also interested in ensuring that growth is economically, socially and environmentally sustainable. Social sustainability, it is assumed, requires inequality be kept under a certain limit.

Consider the case of the debate over 'free trade'. Only a very small proportion of critics consider autarky to be an optimal trade policy. The vast majority agrees, like Oxfam, that trade can be beneficial. They disagree, however, with the conclusion that the optimal policy for a developing country is to unilaterally free trade without bargaining for any concessions from rich countries in return. Before they will agree with such a policy, they need to be convinced that it is preferable to the alternative position of a trade policy that includes some trade restrictions, some export support mechanisms, and some environmental, health, or labor regulations that may restrict trade.

Thus the question in most critics minds is not “To Globalize or Not to Globalize?” but "What, and How Much to Globalize?” This way of thinking may be viewed within the context of the broader debate over pro-poor growth. Both Kanbur (2001) and Ravallion (2003) mention this debate in their papers on globalization and poverty. As Ravallion (2003, p.18-19) says: 
“According to some observers "such actions are not needed...Growth is sufficient. Period.” (Bhalla, 2002, p.206) The basis of this claim is the evidence that poverty reduction has generally come with economic growth. But that misses the point. Those who are saying that growth is not enough are not typically saying that growth does not reduce absolute income poverty....They are saying that combining growth-promoting economic reforms with the right [other] policies ..... will achieve more rapid poverty reduction than would be possible otherwise."

\section{Measurement of Poverty and Inequality}

The purpose of this section, and Section 4 after it, is to provide a taste of both the technical (this Section) and philosophical (next Section) issues in the measurement of poverty and inequality that are pertinent to the globalization debate. It is important to understand these issues for two reasons. Firstly, trends in various measures of poverty and inequality are the bread and butter of participants on both sides of the globalization debate. Thus if we wish to understand why the two sides disagree, it is important to understand these trends. That being said, the reader is reminded that despite the claims of both sides, trends in either direction over the modern period of globalization (usually defined as the time since 1980) do not imply causation. This brings us to the second reason that it is important to understand the debate over poverty and inequality measurement. These measures are necessary inputs to any econometric study which does actually attempt to identify causal links between globalization and poverty or inequality. No matter how sophisticated the theoretical model or econometric method is, the fact remains: Garbage in Garbage out.

The importance of improving measurement methodology beyond the current industry standard is argued by Deaton (2004, p.40), who says:

“.. there is no credibility to the claim that globalization has been good for the poor based on a calculation that applies badly measured distributional shares to (upwardly biased) measures of growth from the national accounts. The globalization debate is serious enough that we must genuinely measure the living standards of the poor, not simply assume them. We cannot prove that growth trickles down by assuming that growth trickles down, nor argue that globalization has reduced poverty without measuring the living standards of the poor." 


\subsection{Poverty}

Despite the existence of a multitude of different poverty measures, many of which may be technically superior, the discussion in this section is limited to the world poverty headcount. This particular measure was chosen both because it is the simplest one and because it is arguably the most often quoted in the globalization debate. As will be obvious from the discussion that follows, the calculation of even this most simple of measures involves enough technical detail to confuse the inexpert, and to promote a vigorous scholarly debate.

Table 1 provides a comparison of the most widely cited current estimates of the world poverty headcount. It can be seen that even very rigorous authors have produced different estimates of the same statistic. The reasons for these very different results may be largely explained by a few key differences in method. We discuss these differences below. Also included in the discussion are the claims by some authors that all of the estimates in Table 1 significantly underestimate the level of poverty.

Table 1 - Comparison of Recent World Poverty Estimates

\begin{tabular}{|c|c|c|c|c|c|c|}
\hline \hline $\begin{array}{c}1998 \\
\text { Headcount } \\
\text { (bill.) }\end{array}$ & $\begin{array}{c}1998 \\
\text { Incidence } \\
(\%)\end{array}$ & $\begin{array}{c}\text { Ave. Change } \\
\text { 1987-98 } \\
\text { (mill. p.a.) }\end{array}$ & $\begin{array}{c}\text { Poverty } \\
\text { Line } \\
(\text { \$day) }\end{array}$ & $\begin{array}{c}\text { Source of } \\
\text { Mean }\end{array}$ & $\begin{array}{c}\text { Currency } \\
\text { Conversion } \\
\text { Method/ } \\
\text { Base Year }\end{array}$ & \\
\hline \hline 1.20 & 24.0 & +1.4 & 1.08 & HHS & WBPPP93 & Chen \& Ravallion (2000), Table 2 \\
\hline 2.80 & 56.0 & +22.9 & 2.15 & HHS & WBPPP93 & Chen \& Ravallion (2000), Table 3 \\
\hline 0.35 & 6.7 & -3.3 & 1.08 & NAcc & PWTV6 & Sala-i-Martin (2002a), Table 1 \\
\hline 0.97 & 18.6 & -20.0 & 2.15 & NAcc & PWTV6 & Sala-i-Martin (2002a), Table 1 \\
\hline 0.46 & 9.2 & -30.8 & 1.08 & NAcc & WBPPP93 & Bhalla (2003), Table 1 \\
\hline 0.37 & 7.4 & -22.6 & 1.15 & NAcc & PWTV6 & Bhalla (2003), Table 1 \\
\hline
\end{tabular}

Notes for Table 1:

Ave. Change - total change in the headcount over the period 1987-98, divided by 11 years.

HHS - household survey data

NAcc - national accounts data

WBPPP93 - World Bank Purchasing Power Parity conversion using base year 1993. Uses Elteto, Koves and Szulc method.

PWTV6 - Penn World Tables Purchasing Power Parity conversion using base year 1996. Uses Geary-Khamis method.

Chen \& Ravallion (2000) are essentially responsible for generating the most recent World Bank figures.

Total Headcount and Ave. Change for Bhalla (2003) were calculated from his reported incidence figures, using the same population size as Chen \& Ravallion (2000).

Sala-i-Martin's incidence is based on the total world population, rather than the population of developing countries as used by the other authors. 


\section{Choosing a Poverty Line}

The first step in generating a poverty headcount is to choose a poverty line. Since 1991, the standard poverty line has been approximately \$US1 per day, in purchasing power parity terms. This line was originally chosen as being representative of the poverty lines in low-income countries. ${ }^{13}$ It is also common to report poverty figures for a line set at twice this value, \$US2 per day.

The World Bank's \$1 per day and \$2 per day poverty lines have been criticized for being arbitrary, and arbitrarily too low, which means that they underestimate the number of people living in poverty. ${ }^{14}$ The importance of the choice of poverty line to the estimated headcount can be observed in Table 1. It can be seen that the headcount for the current \$2 per day line is more than twice that for the \$1 per day line. More importantly, the upward trend in the headcount is more than ten times as high using the \$2 per day line. The significance of the choice of poverty line is also highlighted by the latest poverty estimates from the World Bank (Chen \& Ravallion, 2004). They find that the number of people living below \$1.08 per day fell dramatically from 1981 to 2001, by just under 400 million (representing approximately a halving in the incidence of poverty as a fraction of world population). However, the number of people living between the $\$ 1.08$ and \$2.15 lines increased even more, by around 680 million. As a result, the estimated number living under the \$2.15 poverty line actually increased by 285 million between 1981 and 2001 .

While acknowledging that there was an element of arbitrariness to the original choice of $\$ 1$ and \$2 per day, Deaton (2001) argues that the data consistency losses from defining a new poverty line would outweigh any benefits obtained.

\section{Estimating the Incomes of Different Groups within One Country}

There are two main methods of estimating the economic wellbeing of the population of a country. The first is use national accounts data to estimate the mean income, and household-level survey data to estimate the income distribution. The second is to use household survey data to

\footnotetext{
${ }^{13}$ Chen \& Ravallion (2000)

${ }^{14}$ Wade (2002) and Pogge \& Reddy (2003).
} 
directly calculate the incomes of each decile in the income distribution.

Deaton (2003) explains the main difference between these two methods arises from the fact that the household surveys (HHS) lead to a lower estimate of average income than the national accounts (NAcc), and that the difference between the two increases as incomes increase. This is true when comparing richer and poorer countries at the same time period, and when comparing the same countries over time. There are three main causes of this discrepancy. Firstly, richer people tend to understate the income by more than poorer people. Secondly, richer people tend to respond less often to household income or expenditure surveys. Thirdly, according to Deaton (2003), national accounts data tends to overestimate the growth rate of per capita income. On the other hand, Bhalla (2003) has argued vigorously that the national accounts estimates are far more accurate, and accuses the World Bank of biasing their estimates in order to obtain more funding.

The impact of the difference between these two methods is illustrated in Table 1. It is clear that HHS based estimates produce significantly more pessimistic estimates of both the total number of poor, and the reductions in the number of poor.

\section{$\underline{\text { Maintaining Consistency Across Countries }}$}

The third contentious issue in the calculation of world poverty figures is the way in which incomes are compared across countries. The main criticism is that the consumption basket used to estimate purchasing power parities (PPP) does not reflect the consumption patterns of the poor. ${ }^{15}$ The baskets of goods and services used in all the World Bank's PPP calculations are based on a representative national consumption bundle, not the bundle of goods typically consumed by the poor. This means that because basic needs are relatively more expensive in poor countries the use of such 'broad gauge' PPP measures overestimates the purchasing power of the incomes of the poor in developing countries. Wade (2002), Pogge \& Reddy (2003) estimate this effect to be in the order of $30-40 \%$.

A related issue in the comparison of incomes across countries is the way in which the prices

\footnotetext{
${ }^{15}$ Wade (2002), Pogge \& Reddy (2003) and Deaton (2001)
} 
are combined to produce PPP exchange rates. The World Bank uses the Elteto, Koves and Szulc (EKS) method, while the Penn World Tables are based on the Geary-Khamis (GK) method. According to Dowrick (2001) the GK method tends to overestimate the incomes of the poor, while the EKS method leads to a very slight underestimation. This issue is discussed further in the section on the calculation of inequality measures.

\section{Maintaining Consistency Across Time}

The method used by the World Bank and the other authors in Table 1 involves comparison between countries on PPP terms in some specified year, followed by country-by-country, year-toyear adjustments in real income based on national consumer price indexes (CPI). The problem with this methodology, as noted by Deaton (2001), is that the use of a different base year causes changes in poverty estimates that overshadow the magnitude of any real trend. Among other things, this means that poverty headcounts using different base years cannot be compared. As noted by Wade (2002), it was the comparison of headcounts based on two different PPP base years that generated the much cited claim by the World Bank that the poverty headcount had decreased by 200 million over the period 1980 to 1998 .

In addition to the arbitrary changes in poverty headcount that are brought on by updating the PPP base year, there may also be systematic biases. Pogge \& Reddy (2003) argue that ongoing updating of the PPP base year will cause the overestimation of the incomes of the poor to get progressively worse as average incomes rise. This means that over time, as the base year is updated, the poverty headcount will fall, irrespective of what is actually happening to the poor.

The preceding discussion has illustrated that the official World Bank poverty figures are simultaneously attacked from the left on the grounds that they outrageously underestimate the extent of poverty and overestimate the gains made in recent years, and attacked from the right on the grounds that they do exactly the opposite. Both the right and the left claim that the Bank is manipulating its chosen methodology for political reasons. This is an unfortunate state of affairs, which makes it very difficult for disinterested participants in the globalization debate to form an objective opinion. 
There are undoubtedly weaknesses in the current poverty accounting practices of the World Bank that leave it vulnerable to such criticisms. Some of these weaknesses are implicit in the attempt to summarize all the deprivation in the entire world into a single number, and will never be resolved. However, some of the weaknesses can be reduced as methodology continues to evolve and improve. A good first step would be to follow Deaton's (2001) recommendation that a locally validated set of PPP poverty lines be developed and then held fixed, thus eliminating the large variations brought on by changes in PPP base year.

\subsection{Inequality}

The numbers debate over global inequality has every bit of the complexity of that over poverty, plus one additional layer. That additional layer is the question of what sample best represents "world inequality". Should we consider every citizen as a member of a single global income distribution? Or should we recognize the existence of national boarders and talk about 'within country' and 'between country' components of inequality? The answer, of course, is that each measure has its different merits, and each will be preferable in different contexts.

This section will focus on world inequality calculated assuming that there are no borders, referred to from here on as 'world inequality' ${ }^{16}$. This measure has been chosen on the basis of two major merits. Firstly, it is the concept most analogous to the world poverty headcount, which was discussed under the previous heading. Secondly, it is the concept that most represents what globalization is all about. Indeed, one of the reasons that globalization has been associated with a rise in concern over global inequality could be that people are beginning to think more as global citizens. Consumers in rich countries see that the global economy connects them to the very poorest farmers in developing countries, and that makes them feel that they have the power, indeed the responsibility, to make the world a fairer place.

\footnotetext{
${ }^{16}$ Recently two excellent papers (Sutcliffe, 2004; Svedberg, 2004) have been published that provide a more comprehensive picture of the debate over inequality in the age of globalization. These papers cover, among other points, the debate over population weighting in inter-country inequality estimates.
} 
The one major disadvantage of the 'no borders' approach to calculating inequality is that it is possibly the least relevant to policy analysis. Thus it is worth spending a paragraph to summarize a few broadly accepted 'facts' about the other measures and their trends in recent decades. ${ }^{17}$ To begin with, everyone agrees that the lion's share, of the order of two thirds or more, of inequality in the world is due to between-country inequality, and that this share has changed little since 1980. Most experts would agree that since 1980 within-country inequality has increased in more countries than it has decreased. Most would also agree that between-country inequality has increased if all countries are given equal weight. On the other hand, many would also agree that between-country inequality has decreased if countries are weighted by population. ${ }^{18}$ Finally, almost all would agree that the driving force underlying any inequality calculations over the period has been the fact that major economies especially at the very poor end (China and India), but also at the very rich end (US and UK), experienced a combination of growth and increased withincountry inequality.

'World inequality', the measure that we are mostly concerned with in this chapter, is essentially the sum of between-country and within-country inequality. This means that the fact that India and China both grew and experienced increased internal inequality causes estimates of changes in 'world inequality', to consistently lie between the estimates of changes in betweencountry inequality calculated using alternatively unit weights or population weights for each country. ${ }^{19}$ It is, therefore, not surprising that some authors find that world inequality is increasing, while others find it is decreasing.

17 This paragraph based on the reading the following papers: Dowrick \& Akmal (2001), Milanovic (2002), Sala-iMartin (2002a,b), Wade (2002), Ravallion (2003), Crook (2003), Galbraith (2003), Fischer (2003), Loungani (2003)

${ }^{18}$ This latter finding, however, is dependent on whether incomes are compared on exchange rate or purchasing power parity (PPP) terms, with PPP the more widely accepted basis, and the one which more often leads to the conclusion that inequality has fallen. Dowrick \& Akmal (2001) argue that both exchange rate and PPP are biased, and that when the bias is removed from PPP, very little change is found in population weighted between-country inequality over the period 1980-97.

${ }^{19}$ Estimates of a potential upward trend in 'world inequality' are lower than those of between-country inequality because 'world inequality' implicitly weights countries by population. On the other hand, because 'world inequality' accounts for the rise in within-country inequality, the trend is generally higher than that suggested by population weighted between-country inequality alone. 
Though there are many variations in methodology for calculating world inequality, most of the variation in results arises from two sources, both of which were also important to the debate over poverty headcount. The first is the use of national accounts data verses household survey data to calculate mean national income. The second is the use of the purchasing power parity (PPP) verses exchange rate to convert between incomes in different countries. ${ }^{20}$ The impact of these methodological differences on the results obtained can be seen in Table 2, and in graphical form in Figure 1. Note that though the results presented in Table 2 and Figure 1 are based only on the Gini coefficient, the qualitative conclusions of each of the methodologies are robust to the use of several common measures of inequality.

Table 2 - Comparison of Some Recent World Inequality Estimates

\begin{tabular}{|c|c|c|c|c|c|c|}
\hline $\begin{array}{c}\text { Gini } \\
(\text { Start Yr })\end{array}$ & $\begin{array}{c}\text { Gini } \\
(\text { End Yr) }\end{array}$ & $\begin{array}{c}\text { Rate of } \\
\text { Change }\end{array}$ & $\begin{array}{c}\text { No. of } \\
\text { Countries }\end{array}$ & $\begin{array}{c}\text { Source of } \\
\text { Mean }\end{array}$ & $\begin{array}{c}\text { Income } \\
\text { Conversion }\end{array}$ & Source \\
\hline \hline $\begin{array}{c}78.2 \\
(1988)\end{array}$ & $\begin{array}{c}80.5 \\
(1993)\end{array}$ & 0.46 & 91 & HHS & XR & Milanovic (2002), Table 16 \\
\hline $\begin{array}{c}62.8 \\
(1988)\end{array}$ & $\begin{array}{c}66.0 \\
(1993)\end{array}$ & 0.64 & 91 & HHS & EKSPPP & Milanovic (2002), Table 16 \\
\hline $\begin{array}{c}62.8 \\
(1988)\end{array}$ & $\begin{array}{c}64.5 \\
(1998)\end{array}$ & 0.19 & 91 & HHS & EKSPPP & Milanovic forthcoming \\
\hline $\begin{array}{c}62.7 \\
(1988)\end{array}$ & $\begin{array}{c}61.5 \\
(1993)\end{array}$ & -0.24 & 125 & NAcc & GKPPP & Sala-i-Martin (2002b), Table 1 \\
\hline $\begin{array}{c}62.7 \\
(1988)\end{array}$ & $\begin{array}{c}60.9 \\
(1998)\end{array}$ & -0.18 & 125 & NAcc & GKPPP & Sala-i-Martin (2002b), Table 1 \\
\hline $\begin{array}{c}64.2 \\
(1978)\end{array}$ & $\begin{array}{c}60.9 \\
(1998)\end{array}$ & -0.17 & 125 & NAcc & GKPPP & Sala-i-Martin (2002b), Table 1 \\
\hline $\begin{array}{c}63.8 \\
(1980)\end{array}$ & $\begin{array}{c}61.5 \\
(1993)\end{array}$ & -0.18 & 125 & NAcc & GKPPP & Sala-i-Martin (2002b), Table 1 \\
\hline $\begin{array}{c}65.9 \\
(1980)\end{array}$ & $\begin{array}{c}63.6 \\
(1993)\end{array}$ & -0.18 & 46 & NAcc & GKPPP & Dowrick \& Akmal (2001), Table 5 \\
\hline $\begin{array}{c}77.9 \\
(1980)\end{array}$ & $\begin{array}{c}82.4 \\
(1993)\end{array}$ & 0.37 & 46 & NAcc & XR & Dowrick \& Akmal (2001), Table 5 \\
\hline $\begin{array}{c}69.8 \\
(1980)\end{array}$ & $\begin{array}{c}71.1 \\
(1993)\end{array}$ & 0.15 & 46 & NAcc & Afriat & Dowrick \& Akmal (2001), Table 5 \\
\hline \begin{tabular}{c} 
Plas \\
\hline
\end{tabular}
\end{tabular}

Please see notes on following page for further explanation of abbreviations.

20 There are several methods for calculating purchasing power parity, however, most studies use the Penn World Tables PPP figures. These are based on the Geary-Khamis method. See Summers \& Heston (1991) for details. 
Notes for Table 2:

Sala-i-Martin (2002b) actually obtains estimates for all years from 1970 - 1998. Table 2 and Figure 1, however, present only those years that overlap with another study.

Rate of Change - total change in the Gini from start year to end year divided by number of years between.

HHS - household survey data

NAcc - national accounts data

PPP - purchasing power parity. Sala-i-Martin and Dorick \& Akmal use Penn World Tables PPP data, based on the

Geary-Khamis method. Milanovic uses the EKS (Elteto, Koves and Szulc) method to calculate PPP.

$\mathrm{XR}$ - exchange rate

Afriat - an alternative PPP conversion designed to eliminate the biases typically present in GKPPP. See Dowrick \& Akmal (2001) for details.

As was the case with the poverty estimates, the use of household survey data gives a significantly more pessimistic view of recent decades. Using household survey data only, Milanovic (2002, forthcoming) finds that world inequality increased at a rate of around 0.2 Gini points per year. Using national accounts data to find average incomes, Sala-i-Martin (2002b) finds that world inequality decreased at the rate of about 0.2 Gini points per year over the same period. $^{21}$ This is despite the fact that the two had very similar estimates for the initial inequality in 1988.

The work of Dowrick and Akmal (2001) and Dowrick (2001) illustrates the sensitivity of inequality calculations to the choice of currency conversion when national accounts data is used to find average incomes. Dowrick and Akmal (2001) argue that both exchange rates and purchasing power parities (PPP) based on the Geary-Khamis method are biased means of conversion. ${ }^{22}$ To correct for these biases, they recommend and apply a PPP measure based on an Afriat index which they argue is a 'true' money-metric measure of relative utility. Not surprisingly, both the level and the trend in inequality based on Dowrick and Akmals’ Afriat index lie between the corresponding values based on Geary-Khamis PPP and exchange rate. On balance, the Afriat index shows a very slight increase in inequality over the period 1980-93.

${ }^{21}$ Note that the two authors also differ in the PPP conversion method. Sala-i-Martin uses the Penn World Tables data based on the Geary-Khamis method. Milanovic uses the EKS (Elteto, Koves and Szulc) method. As is explained below, this difference also works to exaggerate the difference between the inequality trends identified by the two authors.

${ }^{22}$ Dowrick (2001) discusses the EKS method of calculating PPP in addition to the GK method. He finds that EKS measures of relative incomes are much closer to the 'true' Afriat measures than GK measures. He also finds that while the GK measure leads to a downward bias in estimates of inequality between countries, the EKS measure leads to a slight upward bias. 


\section{Comparison of Some Estimates of World Inequality}

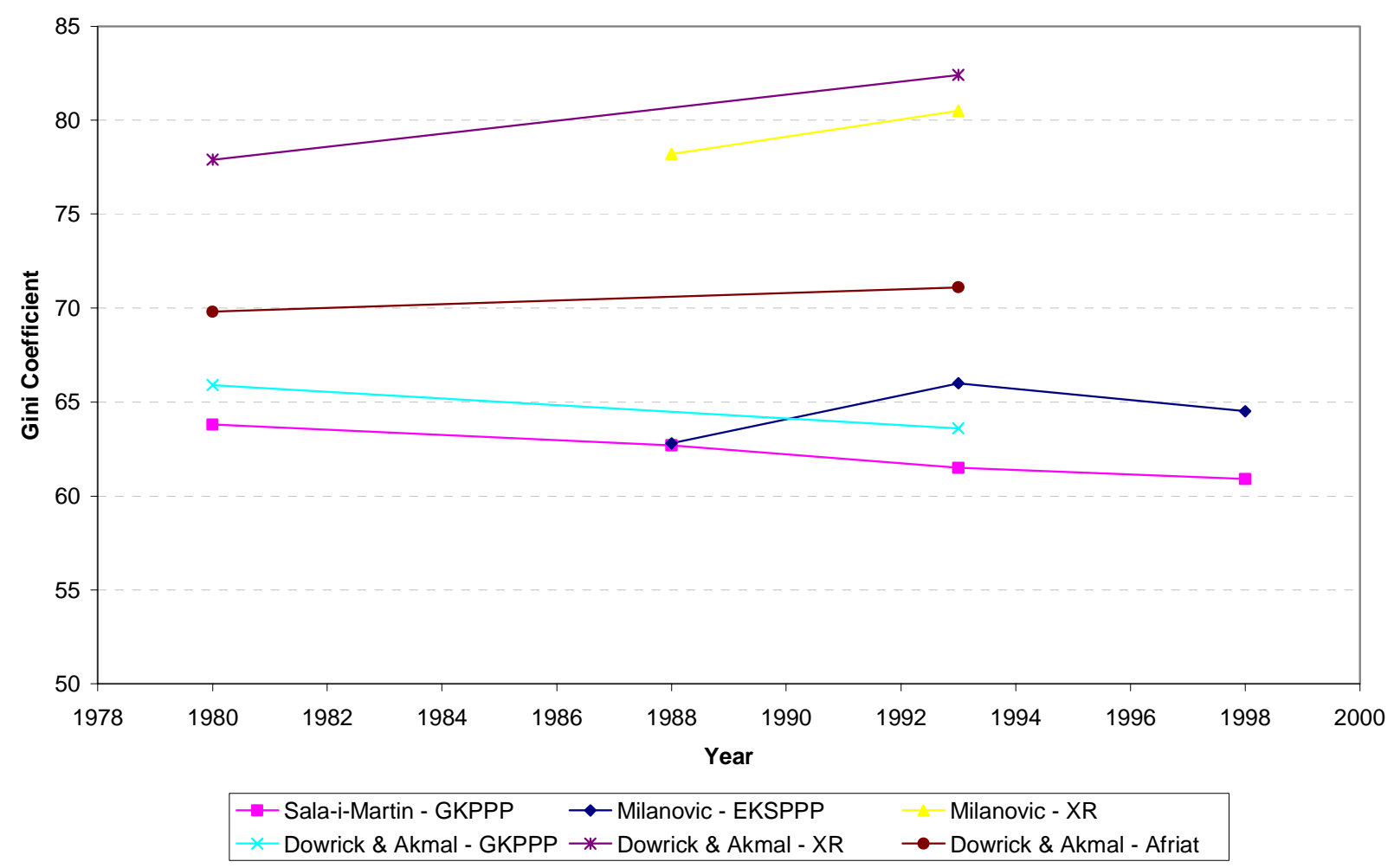

Figure 1 - Graphical Representation of the Numbers in Table 2

According to Sala-i-Martin (2002b), the major difference between his methodology and that of Dowrick and Akmal is that he includes a larger number of countries in his sample. Sala-iMartin notes that the bias in the countries which are excluded from Dowrick and Akmal's sample leads to an underestimate of the increases in inequality over their chosen time period. This would suggest that if the larger sample of Sala-i-Martin was combined with the unbiased PPP conversion of Dowrick and Akmal, we would find that world inequality rose slightly over the period 1980-93. 


\section{Concepts of Poverty and Inequality}

The central question in this paper is why some people believe that globalization is bad for the poor, while others believe quite the opposite. The previous two sections have argued that part of the answer to this question is that the technical literature on globalization and poverty faces methodological issues, some of which simply may not be resolvable to the satisfaction of all sides. However, if technical issues were the only cause, then we would expect to see a world populated by people sitting on the globalization fence, who are awaiting further evidence before coming down on either. This is clearly not the world in which we live.

The following two sections propose two explanations for why the critics have been able to come to such strong conclusions based on the existing evidence. ${ }^{23}$ Firstly, in the current section, we argue that there are subtle differences in values held by critics and proponents, which lead them to interpret the evidence differently. Specifically, it leads them to have different interpretations of value-laden phrases such as 'worsening poverty' and 'growing inequality'. Then in Section 5 we argue that critics and proponents interpret the technical evidence differently because they have different opinions on the 'deep facts ${ }^{24}$, that is, the fundamental processes underlying globalization.

In arguing the importance of values as filters through which people process facts that are presented to them, we follow the tradition of economists and social thinkers such as Robbins (1932), Samuelson (1947), Graaff (1962), and Robinson (1964). More recently, Dasgupta (2004, p.3) says:

"... facts can be as subject to dispute as are values, in part because facts and values are often entangled."

${ }^{23}$ Though the discussion in this paper focuses on why the critics have formed strong conclusions against globalization, the principles here could equally be used to explain to an audience of critics or skeptics why the proponents of globalization have been able to form such strong convictions on the topic.

${ }^{24}$ Dasgupta (2004, p.3) describes ‘deep facts' as "the pathways that characterise social, political, and ecological systems”. 
The implication of people's inherently 'filtered' interpretation of evidence is that, although economists should continue to make every effort to improve the quality of 'the facts' on globalization and poverty, we should not expect that this strategy alone will ever end the debate. As Putnam (1993, p. 146) writes:

"It is all well and good to describe hypothetical cases in which two people "agree on the facts and disagree about values", but ... (w)hen and where did a Nazi and an anti-Nazi, a communist and a social democrat, a fundamentalist and a liberal ... agree on the facts?"

\subsection{Poverty}

This section seeks to identify and explain the concepts of poverty that are most often employed by critics of economic globalization. It will show that the concepts employed by critics tend to be ones that lead to a more pessimistic conclusion about the impact of globalization on poverty. This choice of concepts by critics could be viewed as simply a cynical means of supporting their prior position. However, this section will argue that their choice of definition of poverty is equally well explained by values and social preferences that many critics hold.

This section builds on the work of Ravi Kanbur (2001), who identified several dimensions along which conceptions of poverty tend to vary. They are:

- total number of poor verses poverty incidence,

- monetary verses multi-dimensional measures,

- level of aggregation, and

- time horizon.

\section{Numbers verses Incidence}

Both Ravallion (2003) and Kanbur (2001) observe that the relative importance of the total number of poor and the incidence of poverty is one of the major points of difference in the globalization debate. Academic economists and international development agencies such as the World Bank and UNDP rely almost entirely on incidence as the appropriate measure, while critics 
of economic globalization refer almost without exception to the total number of people living in poverty. The following "Globalization Facts and Figures" reported by the International Forum on Globalization ${ }^{25}$ illustrates this focus.

"Excluding China, there are 100 million more poor people in developing countries than a decade ago. The World Bank, Annual Review of Development Effectiveness, 1999

Since 1980, economic decline or stagnation has affected 100 countries, reducing the incomes of 1.6 billion people. For 70 of these countries, average incomes are less in the mid 1990s than in 1980, and in 43, less than in 1970. - United Nations Human Development Report, 1999”

We can understand the different focus of the two groups very easily if we consider the advantages and disadvantages of the two concepts. If, for example, we want to make inter-country comparisons, then poverty incidence makes much more sense as a measure. ${ }^{26}$ Poverty incidence also allows the poverty outcomes of a policy to be evaluated independent of the impact of population growth. These are all things that economists and development specialists wish to do. These 'poverty professionals' also tend to believe that poverty incidence is a better indicator of how the ease with which poverty could be eliminated in the next period. ${ }^{27}$ Thus a decrease in the poverty incidence is considered to be progress against poverty, even if the total number of poor has not changed or has risen slightly, because the country is now in a better position to fight poverty in the next period. It has also been argued by Sala-i-Martin (2002a) that a veil of ignorance argument suggests that poverty incidence is the more appropriate welfare measure than poverty headcount. He asks where we would prefer our children to be born "in a country of a million people with half a million poor (poverty rate of 50\%) or in a country of two million people and 600,000 poor (a poverty rate of $33 \%$ )".

\footnotetext{
${ }^{25}$ IFG Bulletin, 2001, Volume 1, Issue 3, Available at http://www.thirdworldtraveler.com/Globalization/Globalization_FactsFigures.html

${ }^{26}$ It is possible, however, to conceive of alternative measures that could be used for inter-country comparisons. For example, one could compare "poverty reduction rates" in much the same way that GDP growth is used as the primary measure of overall economic performance.

${ }^{27}$ Consider for example two countries that both have with one million poor people. One country has only one thousand rich people and the other has ten million rich people. It is obvious that the latter country is in a much better position financially to eradicate poverty.
} 
For people outside the economics profession, the utility of a poverty measure as an analytical tool is less important. Their focus tends to be directly on the goal, and that goal is to minimize the number of people that are deprived of basic needs. Further, many would argue that there are ways in which the total number of people remaining poor is a better measure of how easy it will be to eradicate poverty in the future. This view is based on environmental limits or neo-Malthusian perspectives. $^{28}$

As it turns out, using total number of poor or using poverty incidence does make a difference to the conclusions that one draws from an assessment of world poverty trends. Though there is significant variation in the estimates obtained using different methods or different time periods ${ }^{29}$, all of the estimates show a decrease in the incidence of poverty since the 1980s. The total number of extreme poor, however, has been variously found to increase ${ }^{30}$, stay the same ${ }^{31}$, slightly decrease $^{32}$, or significantly decrease ${ }^{33}$. Excluding China, or using a higher poverty line, there is evidence of a significant increase in the total number of poor. ${ }^{34}$

\section{$\underline{\text { Monetary verses Multi-Dimensional Measures }}$}

Kanbur (2001) argues that critics of globalization tend to think of poverty as a multidimensional concept, rather than something that can be fully captured by measures of average income or expenditure. In this regard, critics are now on the same side as the majority of development economists. ${ }^{35}$ Kanbur (p.1085) notes that health and education outcomes are now

${ }^{28}$ The argument is, that if the creation of goods ultimately depends on environmental resources, and those resources are limited, then an increase in the number of poor people in the world is always a bad sign. Thus this group tend to see poverty as the result of lack of access to resources, more than a lack of economic activity.

${ }^{29}$ For discussions of the issues involved in calculating poverty estimates, and the different results obtained see Wade (2002), Ravallion (2003), Deaton (2001), Deaton (2002) as well as the original source articles cited.

${ }^{30}$ World Bank, World Development Report 2000/01

${ }^{31}$ World Bank, World Development Indicators 2001

${ }^{32}$ Chen \& Ravallion (2002)

${ }^{33}$ World Bank (2002). Note that their estimate of a 200mill. reduction in the number of poor is based on comparison of numbers generated by two incompatible methodologies (Wade, 2002).

${ }^{34}$ Chen \& Ravallion (2002). In this paragraph references to the number of extreme poor are based on a poverty line set at approximately $\$ 1 /$ day, while the higher poverty line referred to is $\$ 2.15 /$ day.

35 Thorbecke (2003), Kanji \& Barrientos (2002), Kanbur (2001) 
agreed to be "on a par with income in assessing poverty and the consequences of economic policy”. Evidence of the importance now placed on health and education outcomes is provided by the UNDP's “Human Development Report 2003”, the World Bank's “World Development Report 2000”, the World Bank and UNDP's joint efforts on the “Millennium Goals”.

Though harder to quantify, empowerment, participation, and vulnerability to shocks are also gaining acceptance as important dimensions of poverty. ${ }^{36}$ The inclusion of these additional dimensions seems justified by the priorities of the poor themselves. A major study "Voices of the Poor: can anyone hear us?” was published by the World Bank in 2000. They found that poverty was indeed multi-dimensional, and that lack of material well-being, humiliation, absence of basic infrastructure, illiteracy, illness, and lack of physical assets (as opposed to income) formed the major issues.

The opinions of the poor also seem to suggest that the impact of globalization on their lives is less positive than measures of changes in their average income would suggest. Graham (2001) reports that the perceptions of the poor and middle-class of their welfare change from national integration and liberalization are systematically below what is suggested by their measured income change. Similarly, as Clare Short and James Wolfenson say in the foreword to "Voices of the Poor"37:

"What poor people share with us is sobering. The majority of them feel they are worse off and more insecure than in the past."

People’s self-perceptions, of course, are always prone to subjectivity and bias. So what do external measures of poverty's 'other dimensions' suggest about the impact of globalization? As proponents of globalization like to note, there have been significant improvements in literacy rates, life-expectancy and infant mortality over the last 25 years. ${ }^{38}$ As with the monetary measures, however, the use of numbers rather than incidence tells a somewhat less laudable story. For

\footnotetext{
${ }^{36}$ Kanbur (2001); World Development Report (2000)

${ }^{37}$ Narayan et al. (2000, p.ix)

${ }^{38}$ For example Fischer (2003), Loungani (2003)
} 
example, while the world rate of illiteracy fell by a third between 1980 and 2002, the total number of illiterate adults in the world decreased by a mere $1.4 \%$ over the same period. ${ }^{39}$ Similar patterns hold for other measures such as infant mortality, and access to clean water and sanitation.

Moving beyond an analysis of trends, Wei and Wu (2002) find evidence from an econometric study using data from 79 countries, that a faster increase in trade openness is associated with a faster increase in life expectancy and a faster reduction in infant mortality. However, they find no corresponding evidence for financial integration. Also on the issue of health, Deaton (2004) argues that one's perception of the impact of globalization is also dependent on what one means by globalization. He suggests that the things economists tend to think of in regard to globalization, such as increased incomes and faster diffusion of health related knowledge and technologies, are beneficial to the health of the poor. On the other hand, some of the institutional aspects of globalization, which are the focus of many critics concerns, may not be so beneficial. In particular, he suggests that the General Agreement on Trade in Services (GATS) may restrict the freedom of governments to shape their health delivery systems, and the Trade Related Aspects of Intellectual Property Rights (TRIPs) agreement may make provision of drugs in poor countries, particularly for HIV/AIDS, more expensive than necessary.

With regard to voice and empowerment, proponents of globalization point out that the period of globalization has been accompanied by the spread of democracy. ${ }^{40}$ In contrast, will be explained in Section 5, many critics believe that voice and empowerment are among the first casualties of globalization. They believe that globalization shifts decision-making to higher and higher levels of government, well beyond the potential for meaningful democratic participation from the poor. ${ }^{41}$ These two opinions are not, however, as incompatible as they at first appear. Proponents of globalization seem to be talking about whether or not the system is in each country

${ }^{39}$ Source World Resources Institute 'EarthTrends' database. The world literacy rate rose from $69.3 \%$ in 1980 to $80.2 \%$ in 2002. The total number of illiterate in the world rose from 883 million in 1980 to a peak of 890 million in 1988 and has been falling steadily since then to around 871 million in 2002. This was helped in large part by China in which the number of illiterate has been falling steadily from 222 million in 1980 to 145 million in 2002, and hampered by India where the number has been rising steadily from 250 million in 1980 to 291 million in 2002.

${ }^{40}$ For example Fischer (2003), Micklethwait \& Wooldridge (2000)

${ }^{41}$ See IFG (2003). See also Bardhan \& Mookherjee (2000) who claim that political centralization may exacerbate problems of capture in the presence of inequality. 
is fundamentally democratic, while critics of globalization are talking about the realities of voice and participation within those countries that are already ostensibly democratic.

Aside from the impact on democratic participation, there are two other major claims made against globalization on the basis of non-monetary dimensions of poverty. The first is that it increases vulnerability to shocks, and the second is that reduced tariff revenues and neoliberal policies associated with globalization lead to cutbacks in government services important to the poor.

Kanbur (2001, p.1087) provides a list of the type of services people envisage as being harmed by globalization, but not recorded in monetary measures of poverty:

"If the bus service that takes a woman from her village to her sister's village is canceled, it will not show up in these [monetary] measures. If the health post in the urban slum runs out of drugs, it will not show up. If the primary school text books disappear, or if the teacher does not show up to teach, it will not show up."

Thankfully, there has been a large amount of research effort directed at evaluating the concerns over both vulnerability and government service provision. To attempt to summarize the conclusions of this research is to do a grave injustice to this extensive literature. However, for our purposes, with the help of Winters (2004), we offer the following. Firstly, there is agreement that capital account liberalization can lead to increased macroeconomic volatility in developing countries. ${ }^{42}$ Similarly there is evidence that the removal of government price support mechanisms can increase volatility of income for those dependent on the sale of agricultural commodities. However, the impact of other aspects of liberalization, such as trade liberalization, has been found to be sometimes stabilizing and sometimes destabilizing. Finally, there is little evidence to support the claim that trade liberalization and structural adjustment packages in developing countries lead to cutbacks in the provision of public goods for the poor. ${ }^{43}$

\footnotetext{
${ }^{42}$ Bhagwati (1998), Fischer (2003), Prasad et al (2003)

${ }^{43}$ Winters (2004)
} 


\section{Level of Aggregation and Time Horizon}

It is often perplexing to economists to hear people refer to globalization 'worsening poverty' even in situations in which it is clear that the total number of people in poverty has fallen. Part of the explanation for this puzzling view is that many people consider the phrase 'worsening poverty' to be apposite in any situation in which a significant number of already poor people are made poorer. Kanbur (2001) attributes the greater concern that critics of globalization have for those who lose from the process to a smaller geographical perspective, or lower level of aggregation, and different time horizon. He explains the smaller geographic perspective as follows (Kanbur, 2001, p.1087):

"For an NGO working with street children in Accra, or for a local official coping with increased poverty among indigenous peoples in Chiapas, it is cold comfort to be told, 'but national poverty has gone down'."

With regard to time horizon, Kanbur suggests that critics of globalization have at once a shorter term and a longer-term world-view than many of its proponents. The shorter-term view is the one that leads critics to feel particularly concerned about the loss of income by certain subgroups as a result of globalization-induced changes in the economy. This short-term view is contrasted with the medium term perspective of economists. In the medium term it is argued that globalization will promote new industries, and better jobs will become available to replace those that had been lost.

According to critics of globalization, the pertinent question is whether the people who lost their livelihoods in the short term are likely to be the same ones that gain a new and better source of income in the medium term. In the case of middle aged or older people, or where lack of education and poor geographical mobility limit access to new opportunities, it may be the case that the losers remain losers, for the rest of their life. ${ }^{44}$

\footnotetext{
${ }^{44}$ Ravallion (2003, p.16) provides some empirical evidence in support of this concern. He claims that, when analyzing the poverty impact of economic integration:

“...it is quite common to find considerable churning under the surface. Some people have escaped poverty while
} 
The problem with Kanbur's explanation based on geographical scope and time horizon is that is does not fully complete the picture. His examples of NGO workers and local officials working with the poor do not explain why large numbers of people who work in office jobs in rich countries also appear to use the losses of certain subgroups as their criterion for claiming that globalization has 'worsened poverty'.

I propose a more basic explanation: that people simply do not like to see poor people being made worse off. This could be interpreted as an indication that critics of globalization support a Rawlsian notion of social welfare, as opposed to the utilitarian notion that is popular among economists. Another explanation is that although the rational side of most personalities will tend towards a utilitarian perspective, the social side of those same personalities will find personal tragedies such as the suicide of South Korean farmer Lee Kyung Hae at the WTO meeting in Cancun highly compelling. As behavioral economists are finding more and more, we are often not consistent in our framing of such complex values. More recent evidence from behavioral experiments, suggests yet another potential explanation: the critics are simply displaying a very common human characteristic. After conducting experiments based on hypothetical allocation decisions (unrelated to globalization), Baron (2003, p.1) finds that:

"People are reluctant to harm some people in order to help others, even when the harm is less than the forgone help (the harm resulting from not acting). The present studies use hypothetical scenarios to argue that these judgments go against what the subjects themselves would take to be the best overall outcome."

It seems fair to conclude then, that the balance between greater good and personal losses is a dilemma to which there is no easy solution. Balancing stakeholder and national interest is the perennial challenge for policy-makers. Part of the reason that globalization is so unpopular may be that, in order get past the powerful stakeholders such as the owners of capital in protected industries, policy-makers have had to shift the balance far towards being concerned with the greater national good. In such an environment, the voices of already marginalized groups such as 
peasants and indigenous peoples have almost no chance of being heard.

Seen in the worst light, those middle class white kids protesting in the street in their wealthy countries are trying to stop something that has made many of the world's poor better off. Seen in the best light, they are trying to give a voice to those who otherwise have none, and pushing policy-makers to think harder about how to soften those sharp edges of globalization.

\subsection{Inequality}

Critics of corporate globalization tend to consider the level of inequality to be an important component of social welfare, independent of its impact on poverty. If there is a trade-off between fairness and efficiency, they will lean towards fairness. Interestingly, the mounting evidence from behavioral economics research is that they are not alone. As Fehr \& Schmidt (2000, p.1) find, “many people are strongly motivated by concerns for fairness and reciprocity". And as Ken Rogoff (forthcoming, p.4) says "In the long-run ${ }^{45}$, global social welfare depends fundamentally on fairness and happiness ...”

While the deep psychological reasons that people are concerned with fairness are still being unraveled, some argue that there is a practical basis for concern with inequality. Robert Wade (2002, p.21) provides an example of the practical justification in his argument for why we should be concerned about exchange-rate based inequality between countries:

"It may, for example, predispose the elites to be more corrupt as they compare themselves to elites in rich countries and squeeze their own populations in order to maintain a comparable standard of living. It may encourage the educated people of poor countries to migrate to rich countries, and encourage unskilled people to seek illegal entry ${ }^{46}$. It may generate conflict between states, and-because the market-exchange-rate income gap is so big-make it cheap for rich states to intervene to support one side or another in civil conflict."

${ }^{45}$ In this instance Rogoff was referring to the long-run as the time after which absolute poverty will have been eliminated. As he says in the same paper (p.1): “... we can expect that as global income inexorably expands over the next century, issues of inequality, rather than subsistence, will increasingly take center stage in the poverty debate."

${ }^{46}$ Thomas Straubhaar (1988) finds that net emigration from a poor country to a rich one tends to diminish when the wage differential between the two countries falls below 1:4. Quoted in IMF (Ch4). 
In its Global Trends 2015 report (IFG, 2002, p.30), the U.S. Central Intelligence Agency (CIA) also seemed to think inequality was worth worrying about. According to them globalization would create:

“...an even wider gap between regional winners and losers than exists today. [Globalization's] evolution will be rocky, marked by chronic volatility and a widening economic divide....deepening economic stagnation, political instability and cultural alienation. [It] will foster political, ethnic, ideological and religious extremism, along with the violence that often accompanies it."

Given then, that inequality is a common concern, the question still remains why some people think that globalization leads to more inequality, and others think it leads to less. As with poverty, the explanation lies largely in differences in what people really mean by inequality and 'worsening inequality'. Indeed, the debate over what type of inequality we 'should' worry about is even more intense than that over poverty. The intensity of the debate seems to be fueled by the fact that inequality is a genuinely complex concept. Concepts of inequality vary significantly depending on the person, and depending on the framing of the issue presented to each person (Devooght, 2003; Litchfield, 1999).

In order to keep this paper a manageable length, we must once again apologize to an extensive literature (this time on the philosophical, axiomatic, and social bases for selecting inequality measures), and move on to the evidence that directly relates to globalization. In short, we will argue that critics of globalization tend to think in either absolute dollar terms, or in terms of polarization between the top and bottom of the income distribution. They are also particularly concerned with the distribution of the gains from globalization. In contrast, proponents of globalization, and most academic economists, tend to use distributional measures of relative inequality, of which the Gini coefficient is the most popular. ${ }^{47}$

\footnotetext{
${ }^{47}$ Different statistics regarding the population over which inequality is being measured have also been used to advantage by both sides of the debate. This issue was discussed in Section 3 under "Technical Details Inequality".
} 
Inequality in the Absolute Gains from Globalization

According to both Kanbur (2002) and Ravallion (2003) emphasis on absolute as opposed to relative inequality is the source of much of the perception that globalization is increasing inequality. ${ }^{48}$ In support of this, Ravallion quotes experimental evidence in which $40 \%$ of participants were found to think about inequality in absolute terms. To explain what he means by absolute inequality, he provides the following example. Consider an economy has only two households, one with an income of $\$ 1,000$ and the other with an income of $\$ 10,000$. Distributionneutral growth of in the economy of $100 \%$ would double both incomes, and leave the Gini coefficient unchanged. However, the poorer household now has \$2,000 and the richer \$20,000. This means that the richer household gained ten times as much as the poor household. Many people would not consider this a fair outcome, and would probably describe it as an example of increased inequality, despite the fact that relative inequality is unchanged.

The example above is also relevant to the sweatshop debate. Consider the case of a multinational corporation opening a factory in a developing country. The multinational provides better pay and conditions than similar local enterprises: say $\$ 2.20 /$ day rather than $\$ 1.80 /$ day. For the poor and unskilled in the local community, taking a job in the new factory represents an improvement over their previous standard of living. Meanwhile, as a result of transferring to the new, cheaper location, the multinational makes cost savings \$18 per worker per day. Six dollars of this saving is spent on paying off the investment in the new factory, six dollars is passed on to consumers, primarily in rich countries, and corporate executives collect six dollars as a bonus.

Despite the fact that the above situation clearly describes a Pareto improvement, many critics of globalization would consider the above situation a bad outcome on the basis that it was unfair. They would rather see a greater share of the gains going to the poor workers. This issue is closely related to what Nancy Birdsall (2001, p.3) claims is the major reason for the popular perception that globalization is good for the rich and bad for the poor. According to her:

\footnotetext{
${ }^{48}$ A pleasing development, perhaps in response to this observation, is that two recent surveys of the debate on inequality and globalization (Sutcliffe, 2004; Svedberg, 2004) include figures on and discussion of trends in absolute inequality.
} 
"We economists (and I put myself in that group) are missing the point. True, world poverty may be declining and global inequality no longer rising. But that does not mean that the global economy is fair or just. ...even relatively benign outcomes may belie fundamentally unequal opportunities in an unfair global game."

Combining the insights of Ravallion and Birdsall, we may conclude that many critics are concerned about inequality in absolute gains and in opportunities for gain from globalization.

\section{$\underline{\text { Polarization and Top-Driven Inequality }}$}

Changes in inequality in absolute terms are no doubt important in the minds of many critics. However, a perusal of the internet suggests that there is a second concept of inequality which is also popular among critics of globalization. The statistics most often quoted in support of the negative impact of globalization on inequality are, in fact, measures of the level of relative inequality (cf changes in absolute inequality as discussed above). However, unlike economists' measures, which are based on the entire the income distribution, the figures reported by critics of economic globalization usually refer simply to the polarization of the distribution. ${ }^{49}$ That is, they focus only on the two ends of the distribution, which suggests a particular concern with 'topdriven' inequality. Robert Wade provides an excellent example of the figures quoted on polarization.

"Global inequality is worsening rapidly ...Technological change and financial liberalization result in a disproportionately fast increase in the number of house-holds at the extreme rich end, without shrinking the distribution at the poor end ... From 1988 to 1993, the share of the world income going to the poorest 10 percent of the world's population fell by over a quarter, whereas the share of the richest 10 percent rose by 8 percent."

Statements such as this, which refer to changes in the relative incomes of the top and bottom deciles, are typical of the criticisms of economic globalization that originate in relatively rich

\footnotetext{
${ }^{49}$ The same two recent surveys of inequality and globalization (Sutcliffe, 2004; Svedberg, 2004) that gave attention to absolute inequality also include significant discussion of polarization measures. This shift towards more broadly appealing inequality concepts is to be applauded.
} 
countries. However, according to Carol Graham (2001), top-driven inequality may also be important to the negative perceptions of globalization among the poor and middle class in poorer countries. Graham's argument is that by providing an ever-higher benchmark for comparison, topdriven inequality leads people to under-estimate their own income gains.

Knowing that many people think of inequality in terms of 'absolute gains' and polarization, rather than in terms of Gini coefficients, goes some way to explaining the confidence with which critics of economic globalization assert that it causes increased inequality. The empirical evidence does suggest that people do tend to gain from globalization in proportion to the amount of wealth they already $\operatorname{had}^{50}$, and as Sutcliffe (2004) points out, polarization measures have tended to increase in recent times even when the Gini coefficient is falling. ${ }^{51}$

\section{Dissatisfaction with the Process of Globalization}

"Capitalism is the astounding belief that the most wickedest of men will do the most wickedest of things for the greatest good of everyone."

John Maynard Keynes

"This powerful network, which may aptly, if loosely, be called the Wall Street-Treasury complex, is unable to look much beyond the interest of Wall Street, which it equates with the good of the world."

Jagdish Bhagwati, 1998

According to Bayesian learning theories, the conclusion that a person draws from a given set of information is highly dependent on the prior opinion of that person. Similarly, when faced with a number of conflicting information sources of unknown quality, a person will place the most weight on those sources which agree with their priors. ${ }^{52}$ These theories provide a very substantial

${ }^{50}$ This, as Ravallion (2003) points out, is the correct way to interpret Dollar and Kraay (2001) and Dollar \& Kraay (2002)

${ }^{51}$ This is particularly true for inter-country rather than true 'world' inequality measures, and this effect increases as the polarization measure becomes more extreme. For example, according to Sutcliffe's (2004, p.28) calculations, the ratio of the top to bottom $1 \%, 5 \%$ and $10 \%$ of the world's population has at times risen even when the ratio of the top to bottom $20 \%$ was falling. This provides yet another opportunity for critics and proponents of globalization to disagree on trends.

52 Tenenbaum (2003) 
explanation for why, despite the vast research effort directed at proving whether globalization is good or bad for the poor, large differences in opinion remain. The purpose of this section is to explain why so many people form negative priors about the impact of globalization on the poor.

The answer to our question begins with the observation that many critics view globalization as a process through which power is distilled upward and away from the poor, towards a global elite. As Kevin Danaher (2001), author and public education director of the large, non-profit organization Global Exchange, writes.

"Within the global movement for changing how capital gets invested, there are two key questions being raised. First, who is sitting at the table when the investment decisions get made? Second, what are the values guiding the process?

If the people sitting at the table are a mono-crop (wealthy, white males), then the policies coming from that decision-making process cannot reflect the needs and desires of the rest of us. .. a mono-crop of procorporate voices at the decision-making table will shut out other sectors of society, such as workers, environmentalists, churches, community groups, and others. Thus "democracy" becomes an empty phrase because the diversity of voices that is essential for real democracy is blocked by those with power not wanting to share it."

Though corporate executives are the most often envisaged members of the global elite, critics also see it as including technocrats, bureaucrats, and politicians ${ }^{53}$. John McMurtry (2002, p.202) provides a lucid and impassioned example of concern over the concentration of power associated with globalization in his article “Why the Protesters are Against Corporate Globalization”.

"The ultimate subject and sovereign ruler of the world is the transnational corporation, operating by collective prescription and enforcement through the World Trade Organization in concert with its prototype the NAFTA, its European collaborator, the EU, and such derivative regional instruments as the APEC, the MAI, the FTAA, and so on.

53 See for example this is an ongoing theme in David Korten's (2001) hugely successful book "When Corporations Rule the World" and one entire chapter is titled "Building Elite Consensus". 
Together these constitute the hierarchical formation of the planet's new rule by extra-parliamentary and transnational fiat."

The second half of the answer to our question "Why do people form negative priors about the impact of globalization on the poor?”, is that few non-economists believe that this powerful, selfinterested global elite will make decisions that maximize long-run benefits to the poor. Indeed, the assumption is more commonly that the elite will make decisions that are good for the elite, and that what is good for the elite is almost invariably bad for the poor. ${ }^{54}$ Consider the following quote from the WTO overview on the website of Global Trade Watch. ${ }^{55}$

“The WTO and GATT Uruguay Round Agreements have functioned principally to pry open markets for the benefit of transnational corporations at the expense of national and local economies; workers, farmers, indigenous peoples, women and other social groups; health and safety; the environment; and animal welfare. In addition, the WTO system's, rules and procedures are undemocratic, un-

transparent and non-accountable and have operated to marginalize the majority of the world's people." (emphasis added)

While these statements are somewhat lacking in balance, they do hint at a number of important policy questions that have attracted some academic interest, but are deserving of much more. Of all these questions, the one on which the gap between public concern and academic interest has been the greatest is the role of big business. A reading of the many websites set up to criticize globalization reveals that this issue is the most widely held concern of the general public with regard to globalization. However, if you don't have time to surf the web, evidence of this may easily be found in the titles of the two best selling 'anti-globalization' books; David Korten's

${ }^{54}$ It is worth noting here that this is an area of important difference between critics of the current form of globalization and those that may be truly described as opposed to globalization. The first group includes organizations such as Oxfam International and Greenpeace. These groups are global themselves, and thus their position is that global governance can work, however, the influential global elite needs to be expanded to include civil society in an equally strong role as big business. In contrast, the latter group, which includes most notably the International Forum on Globalization, tend to believe that democracy will deliver better policies than a combination of technocracy and lobby groups, even if the lobby groups are broadly balanced. Further, they argue that democracy cannot function when the representative group exceeds a certain maximum size, which is far smaller than the world population. Thus they argue that global governance is inherently flawed and local, democratic selfdetermination is to be preferred.

${ }^{55}$ (http://www.citizen.org/trade/wto/index.cfm) 
"When Corporations Rule the World”, and Naomi Klein's "No Logo". However, the role of imperfect competition in the context of international trade and theories of multinational firms is less emphasized today than it was twenty years ago. While the importance of departures from perfect competition was emphasized in models of strategic trade and infant industries in the 1980s, in the 1990s economists generally emphasized the importance of global competition in removing instead of enhancing market power.

As the two book titles above suggest, people are concerned about both the political and market power of transnational corporations. Concern about the political power of big business exists independently of concern over globalization. ${ }^{56}$ However, critics believe globalization exacerbates the problem of corporate power in three ways. Firstly, it facilitates the expansion of the richest and most powerful corporations into countries whose governments are more susceptible to capture, and whose populations are far less empowered than those in their home countries. The most commonly cited examples of the problem are the labor conditions of footwear and clothing manufacturers, and damage to health and livelihoods for local populations in the vicinity of oil and mining operations. It is further claimed that protest and unrest by indigenous or labor groups is violently repressed by the national government directly, or paramilitaries, and that the foreign corporation either actively supports the repression, or complicity ignores it. Some of the most commonly cited cases involve Nike and The Gap in Indonesia; Coca Cola in Columbia; Rio Tinto and Freeport McMoran's joint venture in Irian Jaya (a reluctant part of Indonesia); and Shell in the Niger Delta. ${ }^{57}$

The second way in which globalization is believed to exacerbate problems of corporate power is that it involves the strengthening of supra-national institutions, to which they believe large corporations have disproportionate access. The WTO is the most often criticized international

\footnotetext{
${ }^{56}$ A Business Week/Harris Poll published in the September 2000 edition of Business Week showed that 72-82\% of respondents agree that business has gained too much power over too many aspects of American life, while 74-82\% agreed that big companies have too much influence over government policy, politicians and policy-makers in Washington.

${ }^{57}$ To learn more about these claims, simply enter the company name and location in your favorite search engine. Alternatively, visit the high quality site of the Global Policy Forum http://www.globalpolicy.org/ you can enter the key words in their Google driven search facility, or browse by category. The website contains thousands of news articles as well as reports by both NGOs and UN committees.
} 
institution in this regard, and the Trade Related Intellectual Property Rights (TRIPs) agreement is the most often criticized outcome of this perceived influence. ${ }^{58}$ Thirdly, globalization is believed to exacerbate the problem of excessive corporate political power because it is believed to make big business to get even bigger, and power is believed to be proportional to size. ${ }^{59}$

Proponents of globalization often hold a much more optimistic view of the impact of globalization on corporate political power. They argue that corporate input to policy-making can be constructive, and that globalization actually decreases the likelihood of policy capture by industry. The latter point, is supported by the observation that globalization is often associated with increased accountability and openness of national governments, and increased competition for national monopolies. In addition, it is argued that the costs of corruption and excessive regulation are higher in an open economy, leading to increased pressure for institutional reform (Bolaky \& Freud, 2004). There is also empirical evidence to support these proposed linkages (Ades \& Di Tella, 1999; Berg \& Krueger, 2003)

Bardhan (2003 \& forthcoming) suggests that the forces identified by both sides of the debate are likely to be at work. ${ }^{60}$ Consequently, he says, the effect of globalization on the political equilibrium will vary on a country by country basis, and he calls for more systematic empirical studies on the topic.

We turn now to the second major source of concern with 'corporate globalization', that is, increased market concentration. This issue, according to Kanbur (2001, p.1089) is "undoubtedly the most potent difference in framework and perspective" in the globalization debate. Bardhan (2003) and Bhagwati (2002) also note that one of the fundamental differences between globalization's proponents and critics is that the former consider the impacts of market liberalization within a framework of perfect competition, while the latter consider it in the context of highly imperfect competition. Thus, while much economic research has considered the ability of globalization to reduce the market power held by previously monopolistic domestic firms, many

\footnotetext{
${ }^{58}$ See for example Bardhan (2003); Deardorff (2003); Wright et al. (2003)

${ }^{59}$ See for example Renner (2000)

${ }^{60}$ See also Bardhan \& Mookherjee (2000)
} 
critics see globalization as a mechanism by which the oligopolistic reach of the transnational corporations spreads to the furthest corners of the globe.

The important implication of the assumption of a world of imperfect competition is that it makes distortions in both factor and goods markets feasible. ${ }^{61}$ Hence it is possible to believe that the poor are being exploited both in their role as suppliers of inputs, particularly labor, and in their role as consumers of finished products. A classic example of this belief was the debate in India in the mid-1990s. Many small farmers were suffering at the same time as many poor consumers were facing rapidly increasing food prices. The culprits, some claimed, were the rapidly expanding foreign agribusinesses who were acting as 'middle-men' in the food supply chain. ${ }^{62}$

While it is unlikely that foreign agribusinesses were the primary cause of the consumer price hikes in the Indian example, there is some evidence that some large transnational corporations do have market power. Some major world markets are highly concentrated ${ }^{63}$, and business executives continue to strive for greater market share under the belief that this is necessary in a globalized economy. ${ }^{64}$ For example, according to a recent report from the FAO Committee on Commodity Problems (FAO, 2003) market concentration and vertical integration are 'growing realities' in grain and cereal markets, which can be traced in part to trade liberalization, aggressive export

\footnotetext{
${ }^{61}$ E.g. Sethi (2003, p.1) claims that "most modern economies operate under conditions of imperfect competition where corporations gain above-normal profits, i.e., market rent, from market imperfections. Therefore, corporations should be held accountable for a more equitable distribution of these above-normal profits with other groups, e. g., customers, employees, etc., who were deprived of their market-based gains because of market imperfections and corporate power.”

Deardorff (2003) attempts to provide an economic model describing the exploitative power corporations are accused of exercising over labor.

${ }^{62}$ For example, in a speech in late 1998, the then Prime Minister, Shri Atal Bihari Vajpayee said

"A major area of concern for all of us in the supply and distribution of essential commodities is the exploitative role of middlemen. This was evident even in the recent spurt in prices - the difference between wholesale and retail prices of onion, potatoes, pulses and edible oils was sometimes in the 200 per cent to 300 per cent band.

The worst irony is that increased purchase price for the consumer does not mean better sale price for the farmer. Prices of agriculture produce often fluctuate so wildly from year to year due to market manipulations by middlemen, that sustainable crop planning becomes a near impossibility."

See also Shiva (2002), FAO (2001)

${ }^{63}$ For example, in autos, the top five firms account for almost 60 percent of global sales. In electronics, the top five firms have over half of global sales. And, the top five firms have over 30 percent of global sales in airlines, aerospace, steel, oil, personal computers, chemical, and the media. These figures are from Morgan Stanley Capital International and the International Data Corporation, quoted in The Economist, "A Game of Global Monopoly" March 27, 1993, p. Survey 17.

${ }^{64}$ Ghemawat \& Ghadar (2000)
} 
promotion policies, and privatization of government trading entities. Ghemawat \& Ghadar (2000) however, argue that hard empirical evidence that globalization of an industry drives increased concentration of that industry is lacking. Bardhan (2003) suggests that the impact of globalization on market concentration is in need of more empirical investigation. However, he adds that even if the issue is validated empirically, protesters should be lobbying for better anti-trust laws, not more trade restrictions.

\section{Conclusion}

This paper has attempted to explain why criticisms of globalization's impact on the poor continue to abound, despite the general consensus that liberalization promotes growth, and growth is good for the poor. The explanation consisted of four parts. Firstly, many people view the empirical evidence in favor of globalization skeptically because they see globalization as a process through which power is concentrated upward and away from the poor. In particular, they see transnational corporations as gaining a disproportionate amount of both political and market power. Critics of globalization are also firmly of the opinion that corporations will use their increased power in ways that benefit themselves, and harm the poor.

Though these concerns are not without basis, there are mediating factors that make it difficult to conclude that globalization is increasing corporate power, or that increased corporate power is necessarily bad for the poor. On the first point it is important to remember that globalization exposes many previously powerful national corporations to outside competition, and requires greater transparency in government policy-making. On the second point, it may be that the efficiency benefits of large corporations outweigh any losses from increased market power. Thus it would seem that there is room for more empirical research to determine whether the 'corporate globalization' does indeed give the poor cause for concern.

The next part of our explanation focused on the multiplicity of meanings of the phrases 'worsening poverty' and 'increasing inequality'. The discussion in regard to poverty followed on from Ravi Kanbur's (2001) work which identified four major differences between the concepts of poverty employed by globalization's critics and proponents. These four dimensions are: the total 
number of poor verses poverty incidence, monetary verses multi-dimensional measures, level of aggregation, and time horizon. We argued that although level of aggregation and time horizon do appear to be important distinctions, they are both emblematic of a more general concern that the poor should not be the ones to bear the adjustment costs of globalization.

We then examined the implications of each of these different concepts to our assessment of the progress of the last twenty years. It was argued that invariably some groups of poor are adversely affected by globalization, even when a much larger number of poor are made better off. Thus concern for negatively affected subgroups will always lead to a less favorable assessment of the impact of globalization. In the presence of strong population growth, looking at total number of poor rather than poverty incidence also leads to a predictably more pessimistic assessment. However, the implications of including non-monetary dimensions of poverty are less clear. Many people clearly believe that liberalization will lead to negative impacts on non-monetary dimensions of poverty, but the empirical evidence on this mixed.

In regard to inequality we argued that economic research generally applies measures of the shape of the income distribution, while many of the criticisms of globalization are based on polarization and on changes in absolute inequality. The latter concept is related to the observation that the poor often do not have equal access to the opportunities presented by globalization (Birdsall, 2001; Winters et al, 2004). Both polarization and absolute changes in inequality tend to indicate rising inequality more often than the measures of inequality preferred by economists.

The next section showed that there remain important, unresolved methodological issues in the calculation of even the most fundamental poverty and inequality measures. Foremost among these issues are the use of household survey data verses national accounts data to estimate average national incomes, and the method of comparing incomes across countries and over time. Both of these issues have major implications for our assessment of the last twenty years. Until we reach a consensus on them, there will be empirical support for both optimistic and pessimistic views of the period of globalization. 
Global trends over the last twenty years, however, are not the best facts on which to base claims about the benefits or otherwise of globalization. Thorough empirical work, which links specific policy measures to poverty outcomes, provides a far better basis. The empirical work to date has contributed to a broad acceptance that trade and foreign direct investment are growth promoting. Yet much work remains to show which policies can reduce the adjustment costs bourn by the poor, and maximize the share of the benefits they obtain from globalization.

Overall it seems that the difference of opinion between globalization's supporters and critics can be largely explained by differences in prior views and priorities, as well as current ambiguities in the empirical evidence. Rather than viewing criticism as a burden to be thrown off as quickly as possible, policy-makers and researchers alike could do well to heed its message: That 'good' isn't good enough. We owe it to the world's poor to do better.

\section{Bibliography}

Ades, A. \& Di Tella, R. (1999) "Rents, Competition, and Corruption” American Economic Review 89(4): 982-993.

Agenor, P.R. (2002) "Does Globalisation Hurt the Poor?" World Bank Development Research Group Working Paper 2922. Available at http://econ.worldbank.org.

Baldwin, R. (2003) "Openness and Growth: what's the empirical relationship." NBER Working Paper No. w9578. Available at http://papers.nber.org/papers/w9578.pdf.

Bhalla, S. (2003) "Crying Wolf on Poverty: or how the millennium development goal for poverty has already been reached." Institute for International Economics. Available at http://www.iie.com/publications/papers/bhalla0403.pdf.

Bardhan, Pranhab (2003) "Globalization and the Limits to Poverty Alleviation." Mimeo Draft. U.C. Berkeley. Available at http://globetrotter.berkeley.edu/macarthur/inequality/papers/BardhanGlobLimit.pdf.

Bardhan, Pranhab (forthcoming) "The Impact of Globalization on the Poor”, Brookings Trade Forum 2004, Brookings Institution Press.

Bardhan P. \& Mookherjee D. (2000) "Capture and governance at local and national levels" AER 90(2): 135-139.

Baron, J. (2003) "Blind justice: fairness to groups and the do-no-harm principle.” Mimeo, University of Pennsylvania. Available at http://www.psych.upenn.edu/ baron/eq.pdf. 
Berg A. \& Krueger, A. (2003) "Trade, Growth and Poverty: a selective survey." IMF Working Paper WP/03/30. Available at http://www.imf.org/external/pubs/ft/wp/2003/wp0330.pdf.

Bhagwati, J. (1998) "The capital myth: the difference between trade in widgets and dollars.” Foreign Affairs 77(3): 7-13.

Bhagwati, J. (2000) "Globalization in your face - A new book humanizes global capitalism." Foreign Affairs 79(4): 134-39.

Bhagwati, J. (2002) "Coping with Antiglobalization: a trilogy of discontents." Foreign Affairs 81(1): 2-5.

Bhagwati, J. (2004) “In Defense of Globalization” Oxford University Press: New York.

Bhagwati, J. \& Srinivasan, T.N. (2002) "Trade and Poverty in the Poor Countries." AEA Papers and Proceedings 92(2): 180-183.

Bhalla, S. (2003) "Crying Wolf on Poverty: or how the millenium development goal has already been reached." Institute for International Economics Working Paper No. 0403. Available at http://www.iie.com/publications/papers/bhalla0403.pdf.

Bigman, D. Globalization and the Developing Countries: emerging strategies for rural development and poverty alleviation. CAB Publishing: The Hague, The Netherlands.

Bolaky B. \& Freund, C. (2004) “Trade, Regulations, and Growth” World Bank Development Research Group Working Paper w2409.

Bourguignon F. et al (2002) "Making Sense of Globalization: A Guide to the Economic Issues" Centre for Economic Policy Research, London, CEPR Policy Paper No. 8.

Burtless, G. (forthcoming) "Health in an Age of Globalization: a comment on Deaton”, Brookings Trade Forum 2004, Brookings Institution Press.

CEPR (2002) Trade Liberalization and Poverty: a Handbook. CEPR and Department for International Development. London, U.K. Available at http://www.ids.ac.uk/ids/global/pdfs/tlpov.pdf.

Chen, S. \& Ravallion, M. (2000) "How Did the World's Poorest Fare in the 1990s?" World Bank Development Research Group Working Paper w2409. Available at http://econ.worldbank.org/view.php?type=5\&id=1164.

Chihara, Michelle (2002) "Naomi Klein Gets Global" AlterNet. September 25, 2002. Available at http://www.alternet.org/story.html?StoryID=14175.

Crook, C. (2003) “Global inequality and The Economist: a reply to James Galbraith” openDemocracy 15-9-2003. Available at http://www.opendemocracy.com.

Danaher, K. (2001) “People’s globalization vs. elite globalization.” International Socialist Review Issue 19, July-August 2001.

Deardorff (2003) "What Might Globalizations Critics Believe?" RSIE Discussion Paper 492. Available at http://www.spp.umich.edu/rsie/workingpapers/wp.html.

Deaton, A. (1995) “Data and Econometric Tools for Development Analysis” In J. Behrman and T.N. Srinivasan (eds.), Handbook of Development Economics, North-Holland: Amsterdam and 
New York, 1995, v. 3A, pp. 1785-1882

Deaton, A. (2001) “Counting the World's Poor: Problems and Possible Solutions.” World Bank Research Observer 16(2): 125-47.

Deaton, A. (2003) "Measuring Poverty in a Growing World (or measuring growth in a poor world)." NBER Working Paper No. 9822. Available at http://papers.nber.org/papers/w9822.

Deaton, A. (forthcoming) "Health in an Age of Globalization”, In S. Collins and C. Graham (eds.), Brookings Trade Forum 2004, Brookings Institution Press.

Devooght, K. (2003) "Measuring Inequality by Counting 'Complaints': theory and empirics.” Economics and Philosophy 19: 241-263.

Dollar, D. (2001) "Globalization, Inequality, and Poverty since 1980" World Bank Working Paper. Available at http://econ.worldbank.org/view.php?type=5\&id=2944.

Dollar, D. \& Kraay, A. (2001) "Trade, Growth and Poverty." World Bank Development Research Group Working Paper 2615. Available at http://econ.worldbank.org/files/24986_wps2615.pdf.

Dollar, D. \& Kraay, A. (2002) "Growth is Good for the Poor." Journal of Economic Growth 7(3): 195-225.

Dorosh, P. (2001) "Trade Liberalization and National Food Security: rice trade between Bangladesh and India." World Development 29(4): 673-689.

Dowrick, S. (2001) "True International Income Comparisons: correcting for bias in fixed price measures and exchange rate measures.” Presented at the Economic Measurement Group Workshop, $30^{\text {th }}$ March, 2001, University of New South Wales, Australia.

Dowrick, S. \& Akmal, M. (2001) "Contradictory Trends in Global Income Inequality: a tale of two biases.” mimeo Australian National University, March.

Drabek, Z. (ed.). Globalization Under Threat: the stability of trade policy and multilateral agreements. Edward Elgar: Cheltenham, U.K.

Edmonds, E. \& Pavcnik, N. (2002) "Does Globalization Increase Child Labor? Evidence from Vietnam." NBER Working Paper No. w8760. Available at http://papers.nber.org/papers/w8760.

Elliott, K.A., Kar, D. \& Richardson, J.D. (2002) "Assessing Globalization's Critics: talkers are no good doers?" Unpublished Draft. Institute for International Economics. Available at http://www.iie.com/publications/wp/2002/02-5.pdf.

Emmott, B. (2003) "Radical Birthday Thoughts: a survey of capitalism and democracy." The Economist June 28th 2003: S1-S16.

FAO (2001) "Studying Food Supply and Distribution Systems to Cities in Developing Countries and Countries in Transition - Methodological and Operational Guide (Revised Version)" Available at http://www.fao.org/DOCREP/003/X6996E/x6996e07.htm\#bm07.

FAO (2003) "Major Developments and Issues in Agricultural Commodity Markets", Report of the $64^{\text {th }}$ Session of the Food and Agriculture Organization's Committee on Commodity Problems, Rome, 18 - 21 March 2003. Available at http://www.fao.org/DOCREP/MEETING/005/Y8289e.HTM\#P50_18344. 
Fehr, E. \& Schmidt, K. (200) "Theories of Fairness and Reciprocity": evidence and economic applications" Institute for Empirical Research in Economics, University of Zurich Working Paper No. 75. Available at http://www.iew.unizh.ch/wp/iewwp075.pdf.

Fischer, S. (2003) “Globalization and Its Challenges” Richard T. Ely Lecture. AEA Papers and Proceedings. May 2003.

Friedman, T. The Lexus and the Olive Tree: Understanding Globalization Farrar, Straus \& Giroux: New York.

Galbraith, J. (2003) "Globalisation and inequality: The Economist gets it wrong” openDemocracy 11-9-2003. Available at http://www.opendemocracy.com.

Goldberg, P. \& Pavcnik, N. (2003) "The Response of the Informal Sector to Trade Liberalization." NBER Working Paper No. w9443. Available at http://www.nber.org/papers/w9443.

Goldberg, P. \& Pavcnik, N. (2004) “Trade, Inequality, and Poverty: What do we Know? Evidence from recent trade liberalization episodes in developing countries." Brookings Trade Forum on: “Globalization, Poverty \& Inequality: What Do We Know? Where Are We Going?” Washington, DC, May 13-14, 2004.

Graham, C. (2001) "Stemming the Backlash Against Globalisation." Brookings Policy Brief No. 78. Available at http://www.worldbank.org/poverty/empowerment/events/feb03/pdf/graham.pdf.

Graham, C., Birdsall, N. \& Pettinato, S. (2000) "Stuck in the Tunnel": has globalization muddled the middle class?" Brookings Center on Social and Economic Dynamics Working Paper No. 14. Available at http://www.brookings-institution.com/es/dynamics/papers/middleclass/default.htm.

Gray, John. Flase Dawn: the delusions of global capitalism The New Press: New York.

Harrison, Ann (1996) "Openness and Growth: A time series, cross-country analysis for developing countries.” Journal of Development Economics 48: 419-447.

Harrison, Ann (1997) "Sharing the Costs: the Impact of Trade Reform on Capital and Labor in Morocco." Journal of Labor Economics 15(3): S44-S71.

IMF (1997) World Economic Outlook IMF. Washington, D.C. Available at http://www.imf.org/external/pubs/WEOMAY/Weocon.htm.

Institute for Policy Studies (2000) Top 200: The Rise of Corporate Global Power. Institute for Policy Studies. Washington, D.C. Available at http://www.corpwatch.org/upload/document/top200.pdf.

International Forum on Globalization. Alternatives to Economic Globalization: a better world is possible. Berrett-Koehler: San Francisco.

Irwin, D. Free Trade Under Fire Princeton University Press: Princeton, N.J..

Kanbur, Ravi (2001) "Economic Policy, Distribution and Poverty: the nature of the disagreements." World Development 29(6): 1083-94.

Kanbur, R. (2002) “Economics, Social Science and Development” World Development 30(3):47786. 
Kanji, N. \& Barrientos, S. (2002) "Trade Liberalization, Poverty and Livelihoods: understanding the linkages." IDS Working Paper 159. Available at http://www.gapresearch.org/production/wp159.pdf.

Korten, David. (2001) When Corporations Rule the World. Berrett-Khoeler: San Francisco.

Krueger, A. (1980) "Trade Policy as an Input to Development." American Economic Review 70(May): 288-92.

Litchfield, J.A. (1999) “Inequality: Methods and Tools” text for World Bank’s Web Site on Inequality, Poverty, and Socio-economic Performance: http://www.worldbank.org/poverty/inequal/index.htm

Loungani, P. (2003) “Inequality: Now you see it, now you don't.” Finance \& Development September 2003: 22-23.

Marc Lopatin (2003) "Beyond Iraq: US power and global poverty." ATTAC, "Sand in the Wheels". April 23, 2003. Available at http://www.attac.org/indexen/index.html.

Marazzi, M. (2002) “On the Fragility of Gains from Trade under Continuously Differentiated Bertrand Competition” International Finance Discussion Paper Number 735: Board of Governors of the Federal Reserve System.

McKay, A., Winters, L.A. \& Kedir, A.M. (2000) A Review of Emperical Evidence on Trade, Trade Policy and Poverty DFID, Background document for 2nd Dvmt White Paper. London, U.K. Available at http://www.dfid.gov.au.

Micklethwait, J. \& Wooldridge, A. (2000) A Future Perfect: The Challenge and Hidden Promise of Globalization. Crown Business: New York.

Milanovic, B. (2002) "True World Income Distribution, 1988 and 1993: first calculation based on household surveys alone.” The Economic Journal 112(January): 51-92.

Milanovic, B. (forthcoming) Worlds Apart: Measuring Global and International Inequality. Princeton University Press.

Narayan, D. Patel, R., Schafft, K. Voices of the Poor: can anyone hear us? Oxford University Press for the World Bank: Washington D.C.

Oxfam International (2001) Is the WTO Serious About Reducing World Poverty: the development agenda for Doha. Oxfam International. Washington, D.C. Available at http://www.oxfam.org/eng/pdfs/pp0110_WTO_reducing_world_poverty.pdf.

Oxfam International (2002) Rigged Rules and Double Standards: trade, globalization and the fight against poverty. Oxfam and Make Trade Fair. Washington, D.C. Available at http://maketradefair.com.

Pavcnik, N., Blom, A., Goldberg, P. \& Schady, N. (2003) "Trade Liberalization and Labor Market Adjustment in Brazil." World Bank Working Paper No. 2982. Available at http://econ.worldbank.org/files/24465_wps2982.pdf.

PIPA (2002) "International Tade" Americans and the World Digest, Program on International Policy Attitudes, Available online http://www.americansworld.org/digest/global_issues/intertrade/summary.cfm. 
Prasad, E., Rogoff, K., Wei, SJ. \& Kose, M.A. (2003) "Effects of Financial Globalization on Developing Countries: some empirical evidence." IMF Working Paper No. 031703. Available at http://www.imf.org/external/np/res/docs/2003/031703.htm.

Prasad, E., Rogoff, K., Wei, SJ. \& Kose, M.A. (forthcoming) “Financial Globalization, Growth and Volatility in Developing Countries” In Harrison, A. (ed) Globalization and Poverty, NBER.

Rao, J.M. (1998) Openness, Poverty and Inequality UNDP. New York Available at http://www.fao.org/es/seminar/mohanrao.pdf.

Ravallion, Martin (2000) "Prices, Wages and Poverty in Rural India: what lessons do the time series data hold for policy?" Food Policy (25): 351-364.

Ravallion, Martin (2003) "The Debate on Globalization, Poverty and Inequality: why measurement matters." World Bank Development Research Group Working Paper 3038. Available at http://econ.worldbank.org.

Razin, A., Sadka, E. \& Coury, T. (2002) "Trade Openness, Investment Instability and Terms of Trade Volatility." NBER Working Paper No. w9332. Available at http://papers.nber.org/papers/w9332.

Reddy, S.J. \& Pogge, T.W. (2003) "How Not to Count the Poor." Transcript of lecture given at Columbia University, New York, March. Available at http://www.columbia.edu/ sr793/count.pdf.

Reimer, J.J. (2002) "Estimating the Poverty Impacts of Trade Liberalization." Global Trade Analysis Project (GTAP) Working Paper No. 20. Available at http://www.gtap.agecon.purdue.edu/resources/res_display.asp?RecordID=1163.

Rodrick, Dani (2002) "Feasible Globalizations" NBER Working Paper No. w9129. Available at http://papers.nber.org/papers/w9129.

Rodrick, Dani (1997) "Trade, Social Insurance, and the Limits to Globalization" NBER Working Paper No. w5905. Available at http://papers.nber.org/papers/w5905.

Sala-i-Martin, X. (2002a) "The World Distribution of Income (estimated from individual country distributions)." NBER Working Paper No. 8933. Available at http://papers.nber.org/papers/w8933.

Sala-i-Martin, Xavier (2002b) "The Disturbing 'Rise' of Global Income Inequality." NBER Working Paper No. w8904. Available at http://papers.nber.org/papers/W8094.

Sen, A. (2002) "Globalization and Poverty." Transcript of lecture given at Santa Clara University, 29 October, 2002. Available at http://www.scu.edu/globalization/speakers/senlecture.cfm.

Shiva, V. (2002) "Profits Over People: How the World Food Summit in Rome last fortnight buried food rights, and clearly laid the contours of the future the powerful of the world are designing." Frontline, 19(13), Available at: http://www.globenet3.org/Articles/Article_Vandana.shtml.

Summers, R. and A. Heston (1991). "The Penn World Table (Mark 5): An Expanded Set of International Comparisons, 1950-1988.” Quarterly Journal of Economics 106(2): 327-68.

Sutcliffe, B. (2004) “World Inequality and Globalization.” Oxford Review of Economic Policy 20(1): 15-37. 
Svedberg, P. (2004) "World Income Distribution: which way?” The Journal of Development Studies 40(5):1-32.

Tenenbaum, J. (2003) "Bayesian models of human learning and reasoning” Lecture presented at Northwestern University, May 19 2003. Available at http://www.cogsci.northwestern.edu/Bayes/1.mht!1_files/frame.htm.

Thorbecke, E. (2003) “Conceptual and Measurement Issues in Poverty Analysis” Paper prepared for a WIDER Conference on Inequality, Poverty and Human Well-being, Helsinki, Finland May 30 and 31, 2003.

UNCTAD (2002) Trade and Development Report, 2002 UNCTAD. Geneva Available at http://r0.unctad.org/en/pub/ps1tdr02.en.htm.

UNDP (1999) Human Development Report 1999: Globalization with a Human Face . Oxford Available at http://hdr.undp.org/reports/global/1999/en/.

UNU-WIDER (2004) “The Impact of Globalization on the World's Poor” Call for Papers for the First Project Meeting on Conceptual Issues, Helsinki October 29-30, 2004. Available at http://www.wider.unu.edu/welcome.htm.

Vajpayee, S.A.B. (1998) "Prime Minister Inaugurates Chief Ministers Conference to Review the Price Situation” India News Online December 1998. Available at http://www.indianembassy.org/inews/December98/4.htm.

Wade, Robert (2002) "Globalization, Poverty and Income Distribution: does the liberal arguement hold?" LSE Development Studies Institute Working Paper No. 02-33. Draft July 2002. Available at http://www.lse.ac.uk/Depts/destin/w_papers.html.

Winters, L.A. (2000) "Trade, Trade Policy and Poverty: what are the links?" Center for Economic Policy Research (CEPR) Research Paper No. 2382. Available at http://www.cepr.org/Pubs/newdps/dplist.asp?dpno=2382.

Winters, L.A. (2002) "Trade Liberalization and Poverty: What are the Links?” World Economics 25(9): 1339-67.

Winters, L.A., McCulloch, N. \& McKay, A. (2004) "Trade Liberalization and Poverty: The Evidence So Far” Journal of Economic Literature XLII(March): 72-115.

World Bank (2002) Globalization, Growth and Poverty: Building an Inclusive World Economy Washington, D.C. Available at http://www.worldbank.org.

World Bank (2001) World Development Indicators 2001. Washington, D.C. Available at http://www.worldbank.org.

WEF (2002) "People around the World Increasingly Favor Globalization but Worry about Jobs, Poverty and Environment: World Economic Forum Survey of 25,000 Citizens across 25 Countries” Press Release 1 February 2002 World Economic Forum \& Environics International Ltd.

Wright, B.D., Boetigger, S., Graff, G., Pard, P. \& Van Dusen, E.. Intellectual Property Rights for Plant Biotechnology: International Aspects. Unpublished Draft.: Berkeley, C.A.. 


\section{Appendix 1. Summary of Remaining Disagreements}

\begin{tabular}{|c|c|}
\hline Strong Globalizers & Cautious Globalizers \\
\hline Globalization is good for the poor. & Globalization is bad for the poor. \\
\hline $\begin{array}{l}\text { Inequality should not be a concern, as long as poverty } \\
\text { is decreasing. Relative inequality is the appropriate } \\
\text { measure of inequality. }\end{array}$ & $\begin{array}{l}\text { Absolute inequality should be a concern in its own } \\
\text { right, regardless of poverty outcomes. }\end{array}$ \\
\hline $\begin{array}{l}\text { The proportion of the population living in poverty is } \\
\text { the appropriate measure of poverty outcomes. }\end{array}$ & $\begin{array}{l}\text { The absolute number of people living in poverty } \\
\text { matters more than the proportion. }\end{array}$ \\
\hline $\begin{array}{l}\text { Current income-based measures are sufficient for } \\
\text { answering most questions regarding the benefits of } \\
\text { globalization. }\end{array}$ & $\begin{array}{l}\text { Poverty measures should include empowerment and } \\
\text { vulnerability. }\end{array}$ \\
\hline More liberal trade is always better. & $\begin{array}{l}\text { Total trade liberalization may not be the best means } \\
\text { of promoting trade in the longer term, and even if it } \\
\text { is, it may come at too great a cost in terms of social } \\
\text { and environmental policies. Totally free trade is } \\
\text { unlikely to be the optimal policy, and the optimal } \\
\text { policy mix will be case specific. }\end{array}$ \\
\hline $\begin{array}{l}\text { It is optimal for developing countries to unilaterally } \\
\text { liberalize their economies. }\end{array}$ & $\begin{array}{l}\text { Developing countries should refuse to further } \\
\text { liberalize their economies until the major economic } \\
\text { powers genuinely improve access for developing } \\
\text { country exports. }\end{array}$ \\
\hline $\begin{array}{l}\text { The way in which growth is achieved makes little } \\
\text { difference to distributional outcomes; therefore } \\
\text { governments should employ policies that focus on } \\
\text { maximizing growth. }\end{array}$ & $\begin{array}{l}\text { Maximizing short-term growth is not necessarily the } \\
\text { way to produce sustainable reductions in poverty. }\end{array}$ \\
\hline $\begin{array}{l}\text { Governments should place minimal controls on FDI } \\
\text { in order to attract as much as possible. }\end{array}$ & $\begin{array}{l}\text { Governments should place controls on FDI in order } \\
\text { to maximize the welfare gain to the host country. }\end{array}$ \\
\hline $\begin{array}{l}\text { Policies that improve the profitability of large foreign } \\
\text { corporations should be undertaken because these } \\
\text { corporations provide jobs for unskilled workers and } \\
\text { bring in new technology. }\end{array}$ & $\begin{array}{l}\text { Policies that improve the profitability of large foreign } \\
\text { corporations should not be undertaken as the poor } \\
\text { and the environment inevitably pay for the extra } \\
\text { profits gained. }\end{array}$ \\
\hline $\begin{array}{l}\text { Though the provision of safety nets is important, lack } \\
\text { of safety nets should not be used as a reason for } \\
\text { delaying liberalization. }\end{array}$ & $\begin{array}{l}\text { Liberalization should not proceed until adequate } \\
\text { safety nets are in place. }\end{array}$ \\
\hline $\begin{array}{l}\text { Government provision of essential services such as } \\
\text { health, education, water and power is inefficient } \\
\text { and/or corrupt; therefore these activities should be } \\
\text { privatized. This can be done without negative effects } \\
\text { on the poor by provision of subsidies or vouchers. }\end{array}$ & $\begin{array}{l}\text { Government provision of essential services is the } \\
\text { only means of ensuring all the poor have access to } \\
\text { these them at a reasonable standard. Privatization } \\
\text { will have severe negative consequences for the poor. }\end{array}$ \\
\hline $\begin{array}{l}\text { Opening economies to foreign trade and investment } \\
\text { improves competitiveness and eliminates } \\
\text { inefficiencies caused by national monopoly power. }\end{array}$ & $\begin{array}{l}\text { Opening economies to foreign trade and investment } \\
\text { eliminates smaller local firms and further extends the } \\
\text { oligopolistic power of the transnational corporations. }\end{array}$ \\
\hline
\end{tabular}




\begin{tabular}{|l|l|}
\hline \multicolumn{1}{|c|}{ Strong Globalizers } & \multicolumn{1}{c|}{ Cautious Globalizers } \\
\hline $\begin{array}{l}\text { Large reductions in wages in previously protected } \\
\text { sectors is merely evidence that these sectors were } \\
\text { earning monopoly rents that they were sharing with } \\
\text { their workers. }\end{array}$ & $\begin{array}{l}\text { Large reductions in wages in previously protected } \\
\text { sectors send many previously middle class towards } \\
\text { poverty. It is evidence of the shift towards } \\
\text { corporations in relative bargaining power that } \\
\text { accompanies opening. }\end{array}$ \\
\hline $\begin{array}{l}\text { Opening reduces the potential for capture of } \\
\text { economic and political power by local elites. }\end{array}$ & $\begin{array}{l}\text { The evidence is that integration with world markets } \\
\text { is associated with relative increases in the incomes of } \\
\text { the very rich. This makes it difficult to believe that } \\
\text { their economic and political power has shifted } \\
\text { towards the lower income brackets. If anything, local } \\
\text { elites must now share their power with international } \\
\text { elites. }\end{array}$ \\
\hline $\begin{array}{l}\text { Political reform is necessary in many developing } \\
\text { countries; liberalization will provide a catalyst for } \\
\text { reform. }\end{array}$ & $\begin{array}{l}\text { The effect on the political equilibrium will be case } \\
\text { specific, and it is highly possible that liberalization } \\
\text { will have detrimental effects. }\end{array}$ \\
\hline $\begin{array}{l}\text { It is appropriate to have enforceable super-national } \\
\text { trade and investment agreements. They will } \\
\text { ultimately lead to an optimal outcome. }\end{array}$ & $\begin{array}{l}\text { Either: Nation states should not relinquish power to } \\
\text { international bodies, since democracy does not } \\
\text { function at such a high level. }\end{array}$ \\
$\begin{array}{l}\text { Or: Economically oriented international bodies such } \\
\text { as the WTO need to be balanced by equally powerful } \\
\text { international organizations whose primary concerns } \\
\text { are social and environmental. }\end{array}$ \\
\hline
\end{tabular}

